第54回 全日本鍼炎学会学術大会（福岡）

\title{
ワークショップII 経穴研究委員会
}

\section{経絡・経穴の解剖学的並びに臨床的検討}

山田 鑑照1)、尾崎 朋文2)、松岡 憲二 ${ }^{3)}$ 、坂口 俊二4)、王 財源 ${ }^{4}$ 森川 和宥 ${ }^{5)}$ 、森 俊豪 ${ }^{2}$ 、吉田 篤( 、北村 清一郎 ${ }^{7)}$ 、米山 榮 ${ }^{8)}$ 、谷口 和久 ${ }^{3)}$

(社) 全日本鍼尒学会研究部経穴研究委員会

1）トライデントスポーツ健康科学専門学校

2）森ノ宮医療学園専門学校

3）明治東洋医学院専門学校

4）関西鍼众大学

5）東洋医療専門学校

6) 大阪大学大学院歯学研究科高次脳口腔機能学講座

7）徳島大学大学院ヘルスバイオサイエンス研究部 口腔顎顔面形態学分野

8）米山クリニック

\section{要 旨}

経穴研究委員会（前経穴委員会）は福岡で開催された第54回全日本鍼炎学会学術大 会ワークショップாにおいて、経絡・経穴について3つの検討テーマを 6 名の委員によ り報告した。

第 1 テーマ: 経絡・経穴の解剖学的検討

1）経絡と類似走行を示す解剖構造について（松岡憲二）：遺体解剖による経絡の走行 之神経・血管の走行との類似性についての研究。

2）上肢経絡・経穴の肉眼解剖学的研究 (山田鑑照) : 豊田勝良元名古屋市立大学医学 部研究員の学位研究である上肢経絡・経穴の解剖学的研究紹介並びに山田の研究 として皮下における皮神経・血管の走行と経穴・経絡との関係についての報告。

第 2 テーマ：日中における刺鍼安全深度の研究

1）中国における刺鍼安全深度の研究と進展状況（王財源）：中国刺鍼安全深度研究で 権威のある上海中医薬大学解剖学教室厳振国教授のデータの紹介と最近の中国に おける刺鍼安全深度研究の進展状況報告。

2）経穴の刺鍼安全深度の研究を顧みて（尾崎朋文）：尾崎が今まで発表してきた経 穴部位の刺鍼安全深度の研究並びに厳振国教授のデータと同じ経穴との比較研究。

第 3 テーマ: 少数経穴の臨床効果の検討

1）少数穴使用による鍼炎の臨床効果（坂口俊二）：1４穴使用による鍼炎臨床効果

（連絡先）山田鑑照 T461-0032 愛知県名古屋市東区出来町 1-10-19

Yamada Kansho, 1-10-19, Deki-machi, Higashi-ku, Nagoya, Aichi461-0032, Japan,

E-mail: kansho@va.starcat.ne.jp 
ついての医学中央雑誌文献の検索・分析。

2）合谷一穴への各種鍼刺激が皮膚通電電流量に及ぼす影響（森川和宥）：合谷穴一穴 への置鍼刺激、直流電気鍼刺激、鍼通電刺激が皮膚通電電流量に及ぼす影響につ いての研究。

キーワード：経絡、経穴、神経、血管、刺鍼安全深度、鍼众、少数経穴、臨床効果

\section{I . 経絡と類似走行を示す解剖構造について} 松岡憲二、谷口和久、吉田 篤、北村清一郎

1.はじめに

経絡は「気・血」の運行経路として重要視され ており、西洋医学には存在しない東洋医学独特の 概念を有している。鍼尒治療においては罹患部位 と共に、遠隔部位も治療点として頻用されており、 罹患部位と治療点としての遠隔部位を結びつける 根拠の一つとして、経絡という概念が求められて いる。しかし、経絡の実体は未だに解らず、実体 がないにもかかわらず機能を有するとし、経絡の 重要性が機能面からの概念のみで提唱されている。 今回、体表を走行する経絡に着目し、経絡と一致 もしくは類似した走行を示す解剖構造があるのか 否かを、ご遺体を用いて肉眼解剖学的に検索し、 経絡図と対比して検討をおこなった。

\section{2. 方 法}

解剖は昭和 62 年から平成 8 年の間に行われ、 大阪大学歯学部にご献体頂いた系統解剖実習用遺 体を用いた。解剖は通常の方法で表層から深層へ と進め、その過程で見られる構造（動脈・静脈・ 神経など）の走行を観察した。観察部位はほぼ全 身にわたり、1. 頭部、2. 顔面、3. 上肢の前側 後側、4. 胸部、5. 腹部、6. 背部、7. 殿部 - 大 腿、8. 下腿の内側 - 前面外側 - 後側、9. 足の内 側・外側とした。

\section{3. 結 果}

経絡と全て走行の一致する単独の解剖構造は見 られなかったが、類似した走行を示す解剖構造 (動脈・静脈・神経) が種々の部位で見られた。

(1) 頭部

1)頭頂部・側頭部における経絡走行
頭部を走行する経絡には、頭頂部正中を後頭部 から前頭部に向けて走行する督脈経（ピンクライ ン)、その外方 1 寸 5 分で前頭部から後頭部に向 けて走行する足の太陽膀胱経（黒ライン）、およ び側頭部において外眼角から耳介の前方、上方、 後方へと向かい、後頭部から再び前頭部へ行き、 再度、前頭部から後頭部に向けて走行する足の少 陽胆経（青ライン)がある（図 1)。

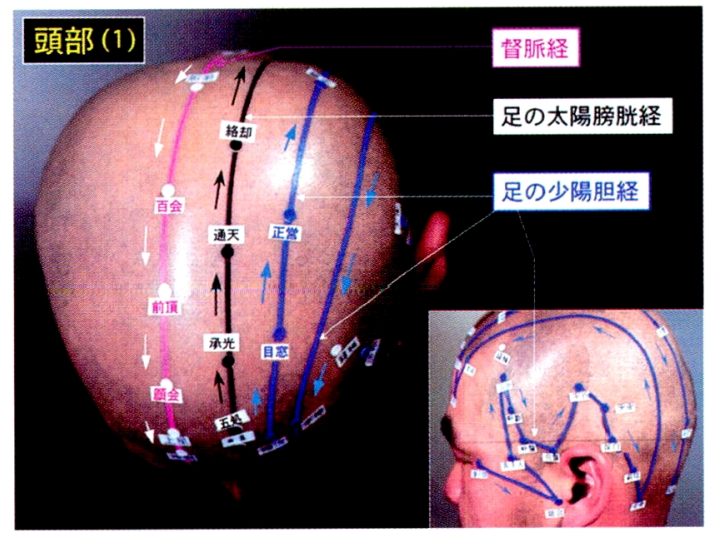

図 1 頭頂部・側頭部における経絡走行

2)前頭部を走行する経絡と解剖所見

図1の経絡走行を前頭部から見る。図2右は同 部位での解剖所見を示す。前頭部を走行する経絡 が、三叉神経第一枝の枝である滑車上神経と眼窩 上神経およびそれに伴う眼窩上動脈の走行に類似 する (図2)。

3) 後頭部を走行する経絡と解剖所見

後頭部を走行する足の少陽胆経と同部での解剖 所見を示す。解剖所見で後頝部から頭頂部へと分 布する大後頭神経と後頭動脈、および耳介後方で 胸鎖乳突筋後縁から側頭部を向から小後頭神経が 見られる。同経絡の走行がこれらの神経・血管の 分布に類似する (図 3)。

4) 側頭部を走行する足の少陽胆経と解剖所見 


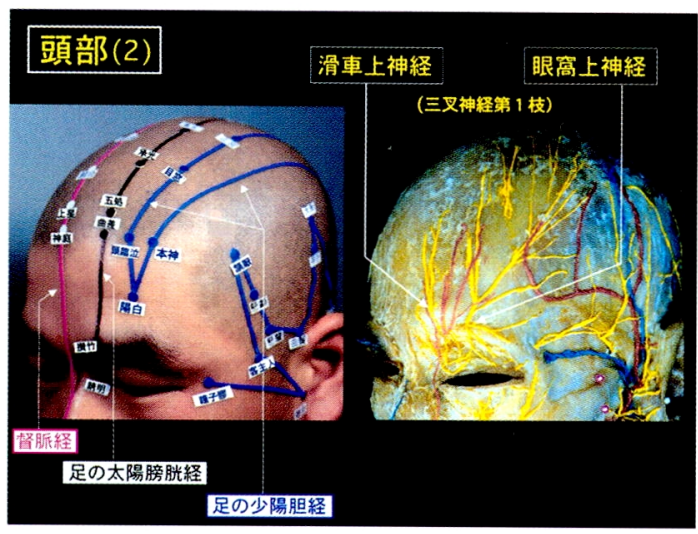

図 2 前頭部を走行する経絡と解剖所見

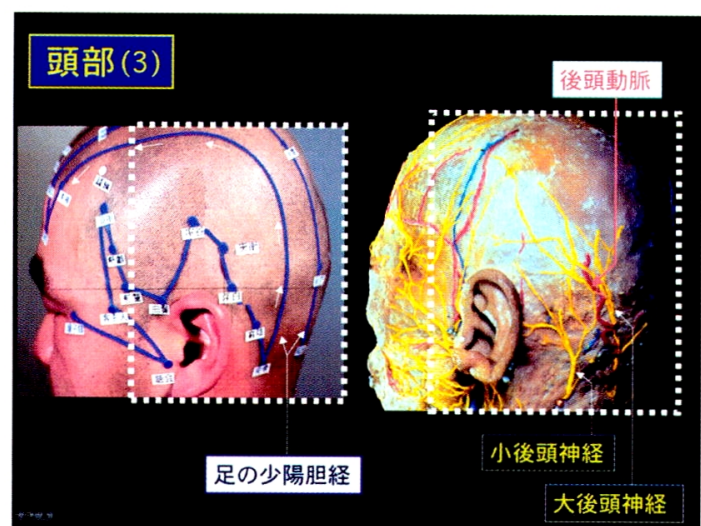

図 3 後頭部を走行する経絡と解剖所見

図 4 上は側頭部における足の少陽胆経の走行で、 外眼角の瞳子髎（GV1）から耳珠前方に向かい、 耳介上方を巡って乳様突起後方の完骨（GV12） に至り、再び前頭部に向うという複雑な走行過程 を示す。

図4下は、同部位の解剖所見で、三攴神経の分 枝である煩骨神経の煩骨顔面枝と㚘骨側頭枝、耳 介側頭神経、および顔面神経の側頭枝が分布し、 各箇所において経穴部之一致するのが伺える（図 4)。

\section{(2) 顔面}

1)顔面を走行する足の陽明胃経と解剖所見

顔面部を走行する足の陽明胃経と同部位での動 脈の分布を示す。総頚動脈は舌骨の高さで内頝動 脈と外頝動脈に分岐し、顔面には外頸動脈の枝で

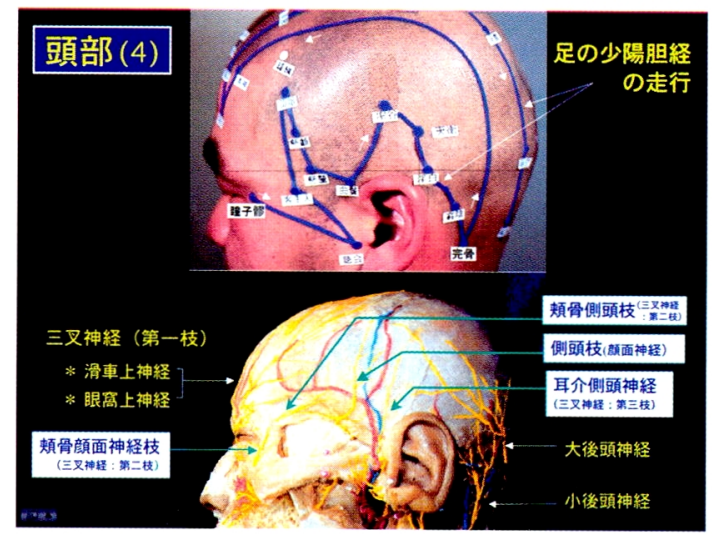

図4 側頭部を走行する足の少陽胆経と解剖所見

耳介前方を走行する浅側頭動脈と、下顎角前方よ り顔面に現れる顔面動脈が分布する。顔面動脈は、 さらに下唇動脈之上唇動脈、および内眼角に向か う眼角動脈に分かれる。経絡走行と対比すると、 承泣（ST 1）から大迎（ST 5）までの流れ（眼窩 下部から瞳孔線上を下行）は眼角動脈から顔面動 脈に、㚘車（ST 6）・下関（ST 7）・頭維（ST 8） の各経穴の流れは浅側頭動脈に、人迎（ST 9）・ 水突（ST 10）の各穴などは総頝動脈の走行に類 似する (図 5)。

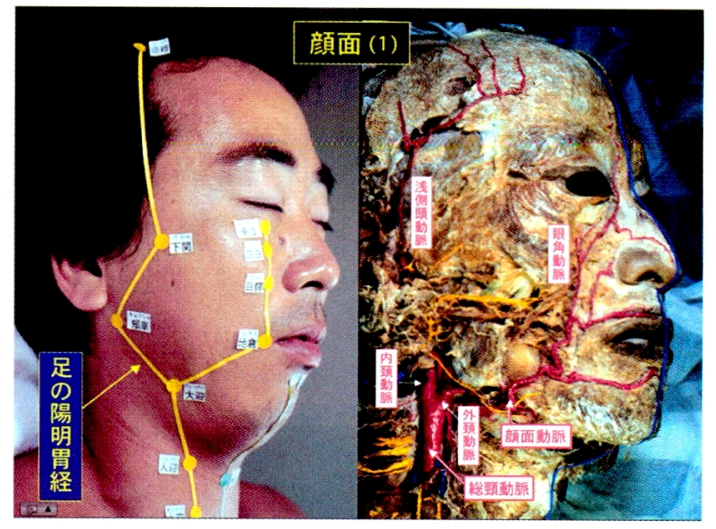

図 5 顔面を走行する足の陽明胃経と解剖所見

\section{2)顔面における大腸経から胃経への接続様相}

図6左は手の陽明大腸経（黄線）から足の陽明 胃経（赤線）への経絡の接続を示したもので、手 の陽明大腸経の最後の経穴＝迎香（LI20）より 上行して、両目中央の鼻根部で左右相交叉し、足 の太陽膀胱経の睛明（BL 1）を経て眼窩下縁中央 
の承泣から四白（ST 2）・ 巨䯘（ST 3）・地倉（ST 4）へと足の陽明胃経に連絡する絡脈の様相を示 している。

図6右は顔面部での動脈分布で、解剖は右側の タ行い、コンピュターにより反転合成し、顔面全 体の動脈分布として表示した。両側の上唇動脈と 眼角動脈の走行をうまくたどると、図6 左で描い た手の陽明大腸経から足の陽明胃経への絡脈の様 子を描くことが出来る（図6）。

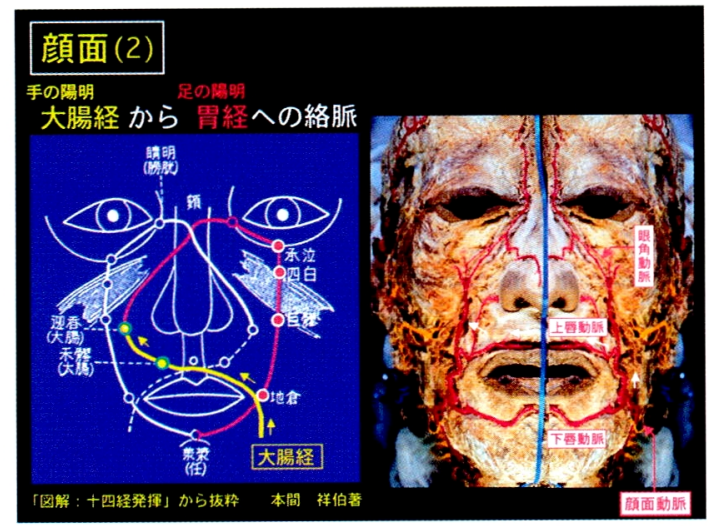

図6 顔面における大腸経から胃経への接続様相

\section{（3）上肢}

1）上腕内側における解剖所見と手の三陰経の走行 図7上は上腕内側部の解剖所見を、図7下は手 の三陰経の経絡走行を示す。腕神経叢より外側神 経束を経て構成された筋皮神経は、腋窝で烏口腕 筋を貫き、上腕二頭筋と上腕筋との間を通つて肘 窩の上腕二頭笳腱橈側に至る。この様相は手の太 陰肺経の走行に類似する。内側・外側の神経束よ り構成された正中神経は上腕動・静脈に伴い、上 腕二頭筋の内縁下部を通つて时窩に至る。この様 相は手の㷧陰心包経の走行に類似する。内側神経 束を経て構成された尺骨神経は上腕三頭筋の内側 上縁を通り、上腕骨内側上顆のすぐ後の小海（SI 8）を走行する。小海は手の太陽小腸経に属する が、この直前までの様相は手の少陰心経の走行に 類似する(図7)。

2) 前腕屈側と手掌における手の三陰経の走行と 解剖所見

前腕屈側から手掌に至る経絡と同部位での解剖 所見を示す。前腕屈側を通る経絡は手の三陰経と

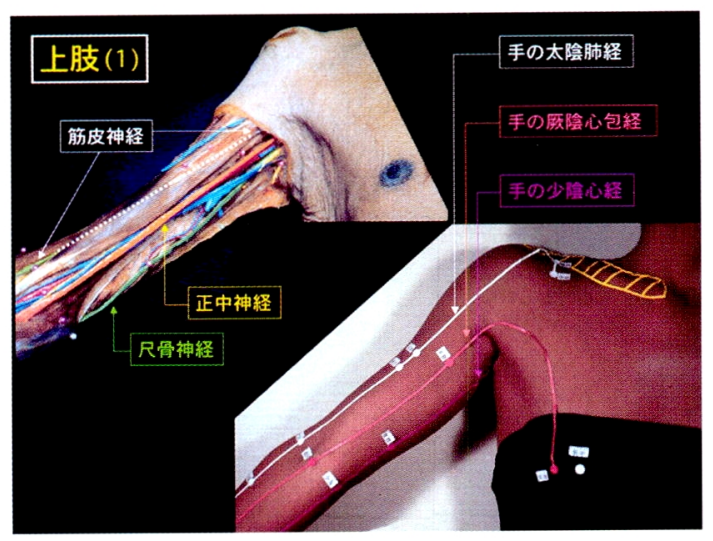

図7 上腕内側における解剖所見と手の三陰経の走行

呼ばれ、橈側に手の太陰肺経、中央に手の厥陰心 包経、尺側に手の少陰心経が走行する。図8下は 円回内筋を尺側へ反転、腕橈骨筋・橈側手根屈筋 . 長掌筋を除去した状態を示す。手の太陰肺経の深 部には橈骨神経の浅枝が走行し、近傍を橈骨動・ 静脈が走行する。手の劂陰心包経は手掌に至るま で正中神経の走行に類似する。また、手の少陰心 経は手掌の少府（HT 8)・少衝（HT9）に至るまで、 尺骨神経および尺骨動脈の走行に類似する（図 8)。

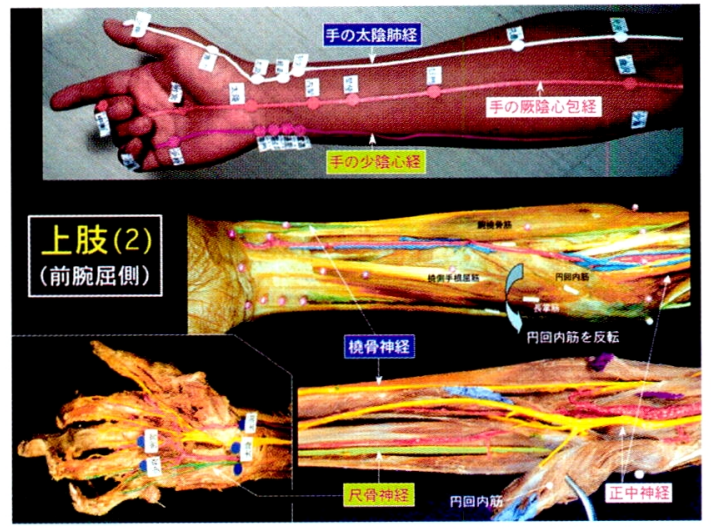

図8 前腕屈側と手掌における手の三陰経の走行と解剖所見

3）前腕伸側と手背における手の三陽経の走行と 解剖所見

前腕伸側を通る経絡は手の三陽経と呼ばれ、橈 側に手の陽明大腸経、中央に手の少陽三焦経、尺 側に手の太陽小腸経が走行する。図9下は皮下の 結合組織を除去し、皮神経と静脈を示したもので ある。個体差もあるが、大腸経は外側前腕皮神経 
と後前腕皮神経の支配域の移行部付近を、三焦経 は後前腕皮神経の支配上を走行する。小腸経は内 側前腕皮神経と後前腕皮神経の支配域移行部付近 を走行する。これら三陽経の走行下にある前腕伸 側の筋は、すべて橈骨神経の支配を受け三陽経と もに同神経が関与している（図9）。

\section{4)橈骨神経浅枝の手背での分布}

図 10 上は手の太陰肺経の列缺（LU7）（肺経の 絡穴）から、手の陽明大腸経の商陽（LI1）と接 続する絡脈の様相を示したもので、図10下は橈 骨神経浅枝の手背部での分布である。絡脈の走行 と同神経の浅枝の走行に類似性が伺える（図 10）。

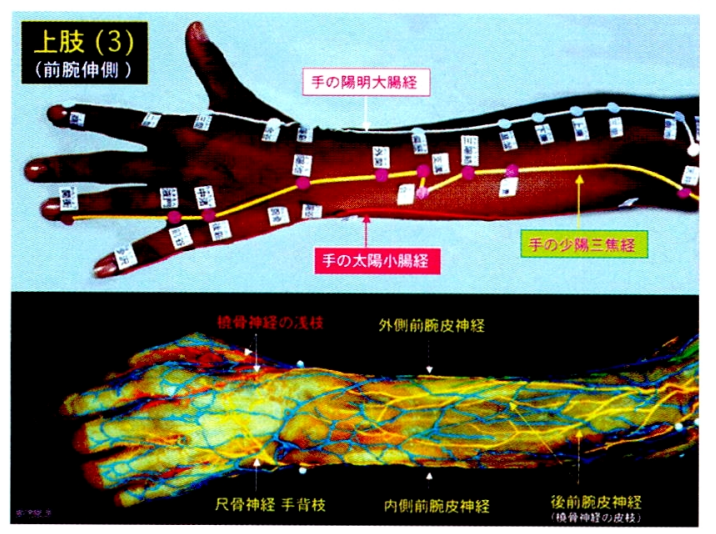

図 9 前腕伸側と手背における手の三陽経の走行と解剖所見

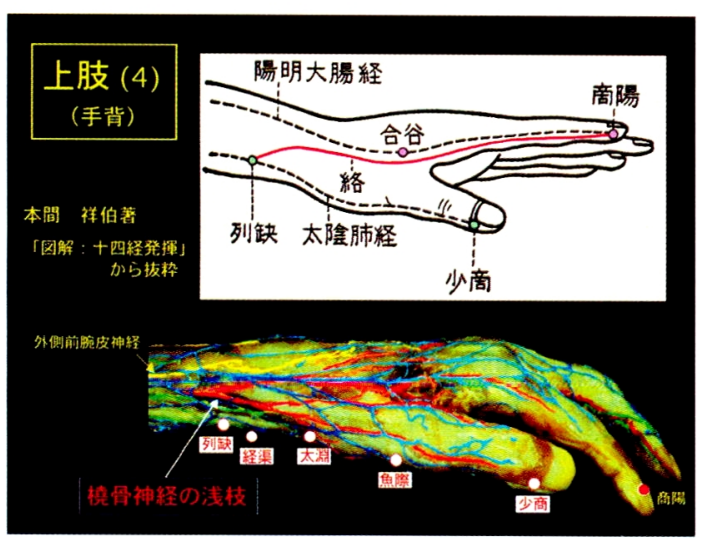

図 10 橈骨神経浅枝の手背での分布

\section{(4) 胸部}

1)胸部を走行する経絡と解剖所見

胸部を走行する経絡および同部位での解剖所見 を示す。図11左において、前正中線上の緑ライ ンが任脈経、次いで外側の黒ラインが足の少陰腎
経、黄ラインが足の陽明胃経、赤ラインが手の厥 陰心包経、白ラインが足の太陰脾経、青ラインが 足の少陽胆経を示す。図 11 右は、各胁間におけ る肋間神経の前皮枝と外側皮枝を示す。縦方向に 流れる経絡走行に対し、横方向に走行する皮神経 との間に違いは見られるが、各肋間に存在する各 経穴はこれらの神経上に位置しており、反点と して出現した部位を縦に連結すれば、経絡に似た 走行とみなすことは可能である（図11）。

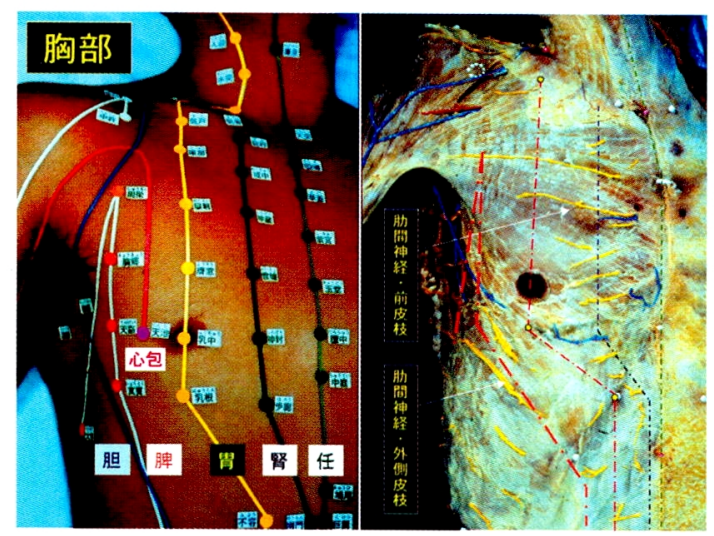

図 11 胸部を走行する経絡と解剖所見

(5) 腹部

1)腹部を走行する経絡と解剖所見

腹部を走行する経絡、および腹直筋や外腹斜筋 を貫いて皮下に現れる胁間神経前皮枝の分布を示 す。各経穴部位とこれら皮神経の位置が類似して おり、胸部同様、反応点として出現した部位を縦 に連結すれば、経絡に似た走行を考えることは可 能である(図 12)。

2) 腹部を縦走する動脈・静脈

図 13 左は腹部の皮下組織中を縦走する浅腹壁 動脈・静脈を示し、右図は腹直筋下を縦走する上 腹壁動脈・静脈および下腹壁動脈・静脈を示す。 縦走する経絡走行を重視するならば同解剖構造が 考えられる。前記、皮神経の反応点と縦走する解 剖構造を付加して考えれば、より経絡に似た走行 を考えることは可能となる（図 13）。

(6) 背部

1) 背部を縦走する経絡および同部位での解剖所見 背部を縦走する経絡および同部位での解剖所見 


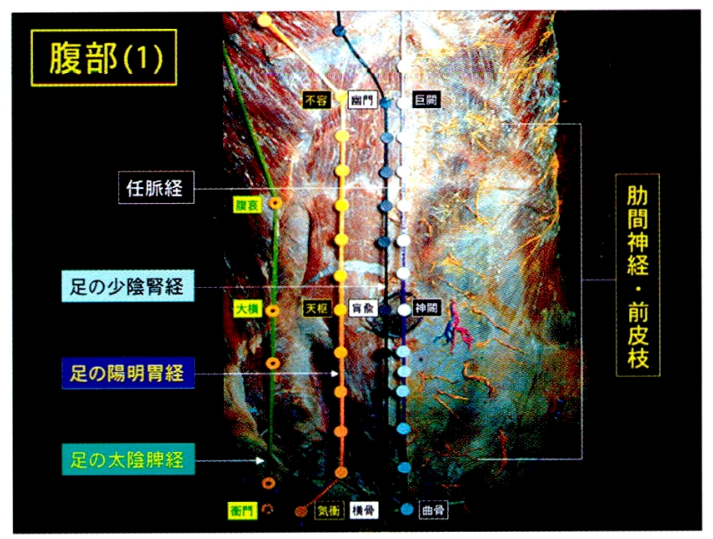

図12 腹部を走行する経絡と解剖所見

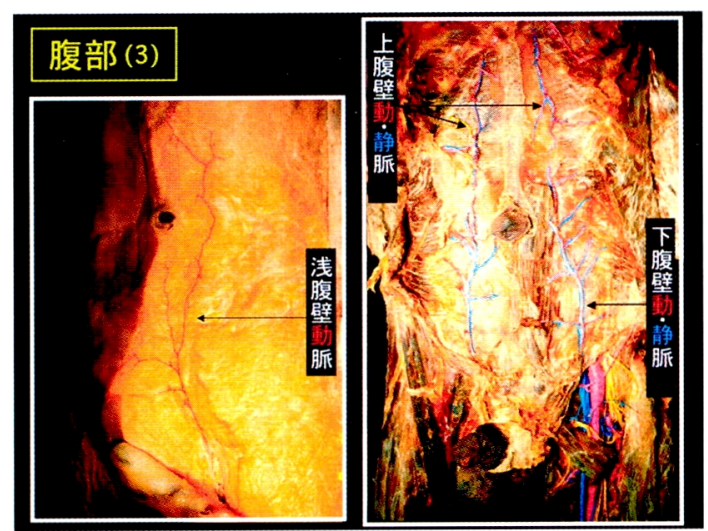

図 13 腹部を走行する動脈・静脈

を示す。背部では後正中線上を督脈経が上行し、 その外方を足の太陽膀胱経の一行線之二行線が走 行す可。図14右は皮神経を剖出したもので、胸 椎棘突起の際および外方から横走する胸神経の後 枝が見られる。縦方向に流れる経絡走行に対し、 横方向に走行する皮神経との間に違いは見られる が、膀胱経の各経穴はこれらの神経上にほぼ位置 しており、反応点として出現した部位を縦に連結 すれば、経絡に似た走行を考えることは可能で、

同神経の皮下での出現部位と経穴部位との間に深 い関連が何える(図 14)。

\section{2) 僧帽筋と神経および動脈・静脈}

背部最浅層の僧帽筋と神経および動静脈を示す。 図 15 左は後正中線で僧帽筋を切断、反転し、裹 面を走行する副神経と頚横動・静脈の走行を示し た。図 15 右は僧帽筋の外形を残し、筋線維を除 去して同神経および動・静脈の走行を示した。同

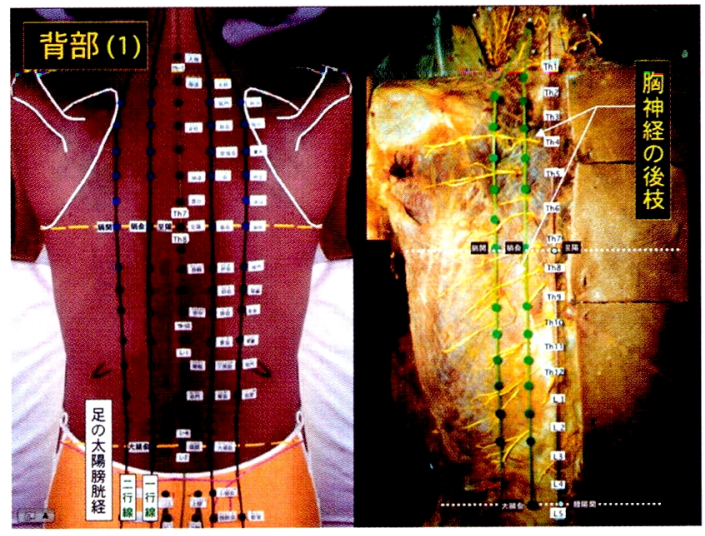

図14 背部を縦走する経絡および同部位での解剖所見

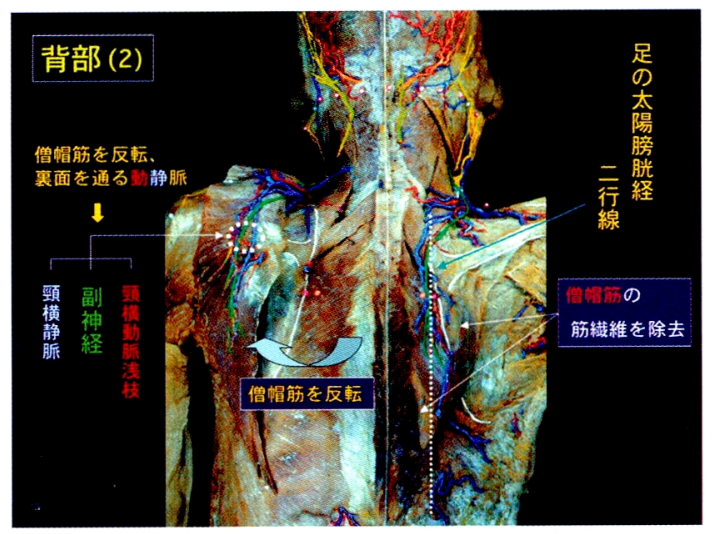

図 15 僧帽筋と神経および動脈・静脈

神経および動・静脈の走行は、足の太陽膀胱経の 二行線上に一致し縦走するのが何える（図 15)。

3) 菱形筋之神経および動脈・静脈

図16左は、僧帽筋の下層に見られる大・小菱 形筋を示す。図16右は菱形筋を反転して、衣面 を走行する肩甲背神経および頚横動・静脈深枝の 走行を示す。同神経や動静脈も膀胱経二行線上の 走行に一致し縦走しているのが何える（図 16）。

\section{（7）殿部・大腿部}

1) 殿部および大腿後面を走行する経絡と解剖所見 殿部と大腿後面には足の太陽膀胱経が走行し、 仙骨上には八髎穴があり、その周辺にも多くの経 穴が点在する。また、膀胱経の一行線と二行線は、 大腿後面を下って膝窩中央の委中（BL 40）で合 流し、下腿後面へと向かう。図17右は仙骨や腰 椎の後壁および腸骨の一部を除去し、仙骨神経叢 


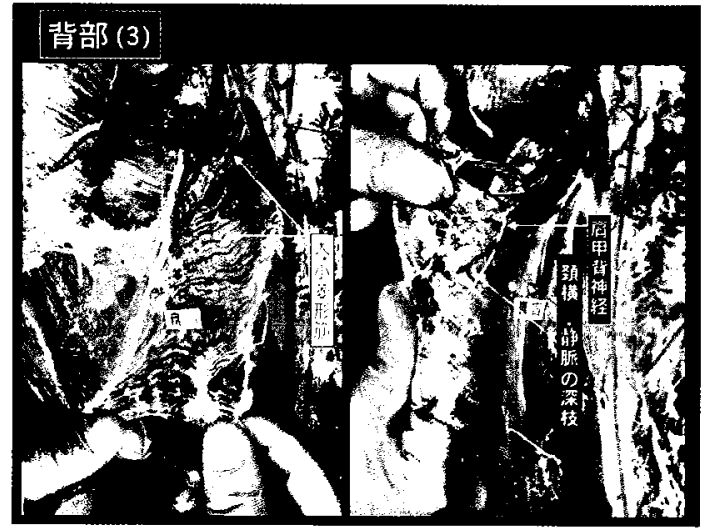

図 16 菱形筋と神経および動脈・静脈

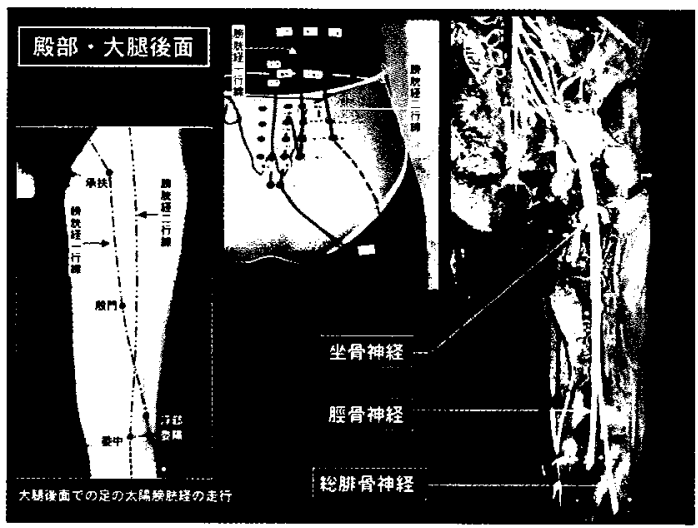

図 17 殿部および大腿後面を走行する経絡と解剖所見

から構成される坐骨神経を示す。坐骨神経は大腿 後面中央を下行し、膝窩の上方で脛骨神経と総腓 骨神経に分岐する。仙骨内部の構成、坐骨神経の 走行および脛骨神経と総腓骨神経への分岐に至る この様相には、膀胱経の走行との類似性を伺わせ る(図 17)。

2)大腿前面の経絡と皮下構造

大腿前面の経絡と皮下構造を見る。黄ラインは 足の陽明胃経、白ラインは足の太陰脾経、青ライ ンは足の㷧陰肝経を示す。上前腸骨棘の下方から 下外方に向かう外側大腿皮神経の走行は、足の陽 明胃経に類似する（ただし、大腿外側に至れば足 の少陽胆経)。また、脾経の走行は大腿神経前皮 枝の走行に、肝経の走行は大腿神経前皮枝や大伏 在静脈の走行に類似するのが伺える（図 18）。

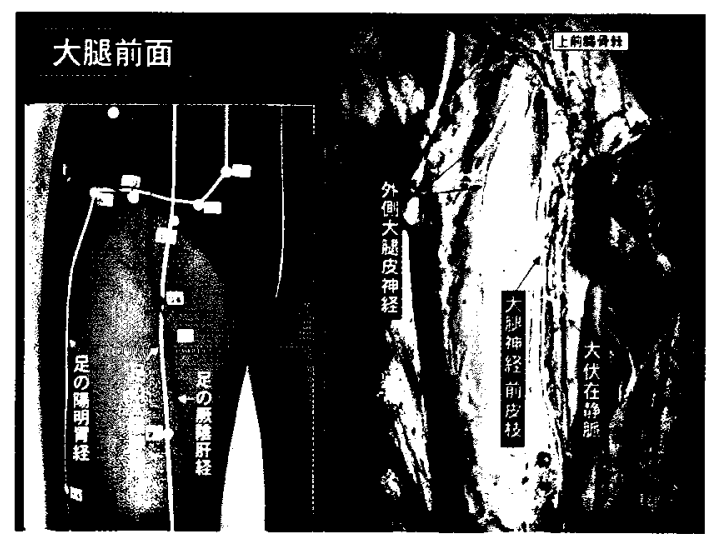

図 18 大腿前面の経絡と皮下構造

\section{(8) 下腿部}

\section{1）下腿内側の経絡と皮下組織}

下腿内側を走行する足の三陰経と皮下の解剖所 見を示す。青ラインは足の劂陰肝経、白ラインは 足の太陰脾経、黒ラインは足の少陰腎経の走行を 示す。母指内側の末端から内果の前を通り、脛骨 の後縁骨際を上行する足の太㓌脾経亡大伏在静脈 の走行に類似性が見られる。また、脛骨内側面上 を上行する肝経は、中都 (VR6) から曲泉（VR 8）に至る間に脾経を横切る様が膝窩横紋内端付 近の曲泉から下腿内側に分布する祭、伏在神経が 大伏在静脈を越える様に類似しており、足の珟陰 肝経は伏在神経の走行に関与していることが何え る(図 19)。

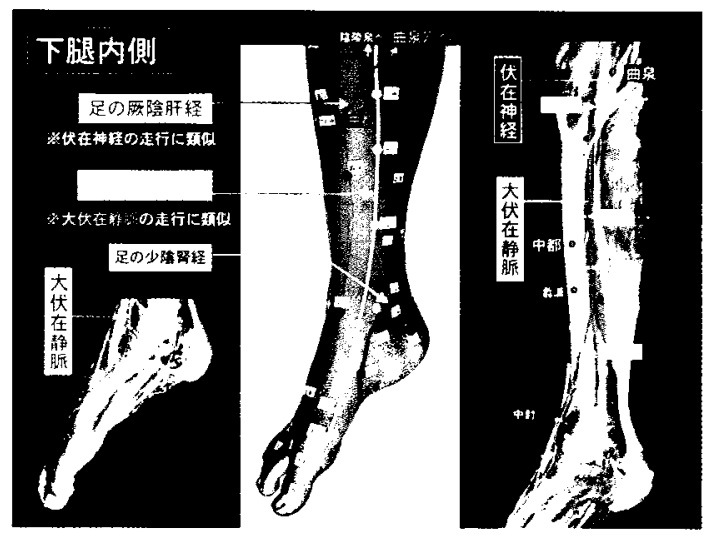

図 19 下腿内側の経絡と皮下組織

2)下腿前面と外側の経絡と解剖所見

下腿前面と外側を走行する経絡と同部位での解 
剖所見を示す。青ラインは足の少陽胆経、黄ライ ンは足の陽明胃経を示す。図20右において、総 腓骨神経が腓骨頭の直下で浅腓骨神経と深腓骨神 経に分岐する。浅腓骨神経は長腓骨筋の起始部を 貫き、長・短腓骨筋の間を下走し、下腿の下半で 皮下に出て外果の前方を通り足背部に分布してい る。この走行は足の少陽胆経に類似する。深腓骨 神経は長腓骨筋と長指伸筋の起始部を貫いて下腿 骨間膜の前面に達する。また、前脛骨動・静脈が 下腿骨間膜の上端を貫いて骨間膜の前面に出現し、 この前脛骨動・静脈と深腓骨神経が下腿骨間膜上 を下行し、足関節前面を経て足背部に達する。こ の様相は足の陽明胃経の走行に類似する（図20）。

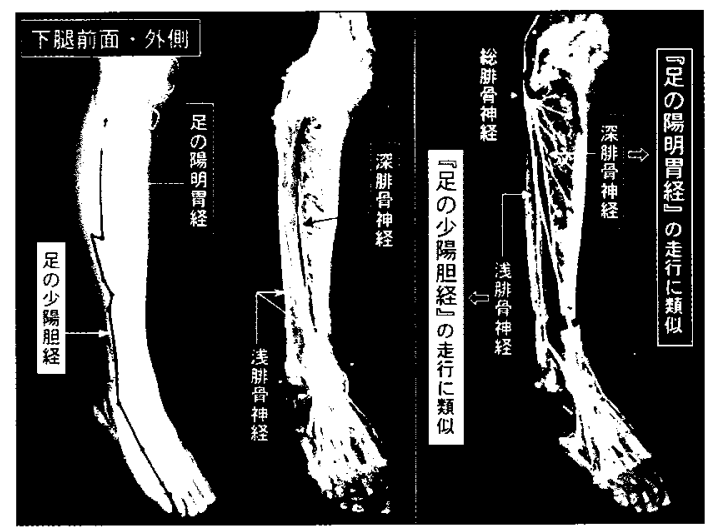

図 20 下腿前側と外側の経絡と解剖所見

\section{3)下腿後面を走行する経絡と解剖所見}

下腿後面を走行する足の太陽膀胱経と同部位で の解剖所見を示す。足の太陽膀胱経は膝窩横紋中 央の委中（BL 40）から外果の後方に向かって下 走するが、膝窩の委中から下腿後面中央の承山 （BL 57）までは、脛骨神経から分枝する内側腓腹 皮神経と小伏在静脈の走行に類似する。下腿下半 では総腓骨神経から分枝する外側腓腹皮神経と内 側腓腹皮神経が合して出来る腓腹神経が、小伏在 静脈と判行して外果後方に向から様相に類似する (図21)。

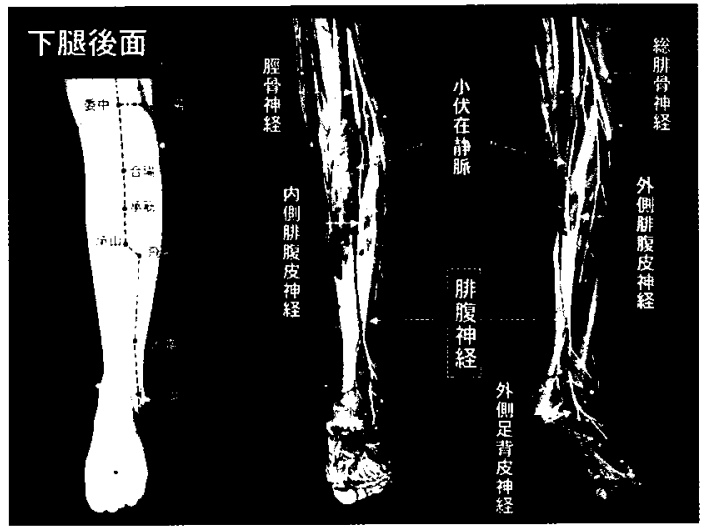

図21 下腿後面を走行する経絡亡解剖所見

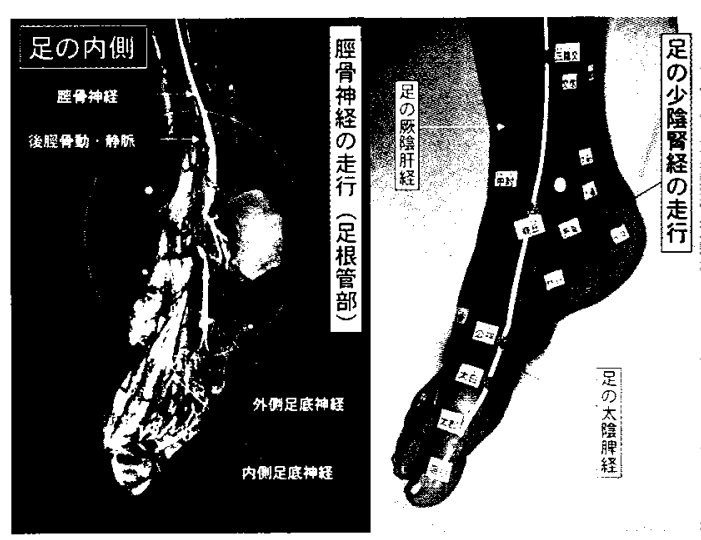

図22 足根管における解剖所見と経絡走行

(9) 足

1) 足根管における解剖所見と経絡走行

足根管における解剖所見と内果後方を走行する 足の少陰腎経を示す。足底に分布する神経や動静 脈は、すべて内果と踵骨の間の足根管を通過し、 同部位を足の少陰腎経が折り重なるように走行す る。足根管には脛骨神経や後脛骨動・静脈が見ら れ、足底から内果後方を巡る足の少陰腎経の走行 に類似するのが同える（図22）。

2)足の外側を走行する経絡と解剖所見

足の外側を走行する足の少陽胆経と足の太陽膀 胱経および同部位での皮神経の分布を示す。足の 少陽胆経は浅腓骨神経の走行に、足の太陽膀胱経 は腓腹神経からの延長である外側足背皮神経の走 行にいずれも類似が伺える（図23）。 


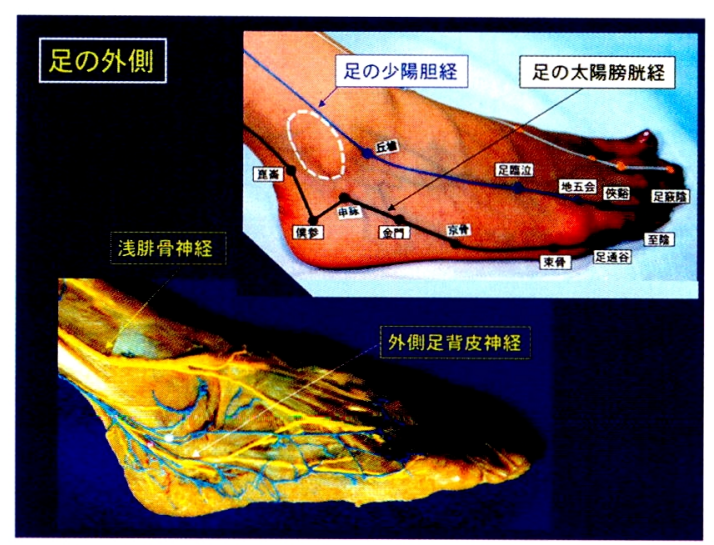

図23足の外側を走行する経絡と解剖所見

\section{4. 考察}

\section{(1)経絡・経穴における経緯}

殷 (西記前 1500 年前後) ・周の時代の産物 ${ }^{1)}$ と される経絡は「気・血」の運行する通路とされ、 東洋医学を代表する最も基礎的概念をなしている。 しかし、経絡の実体に関しては不明な点が多く、 未だ論議が反復されており、これらの論議での意 見には、(1)実体の無の単なる機能的存在として経 絡を否定するもの 2)、(2)組織・解剖から形態学的

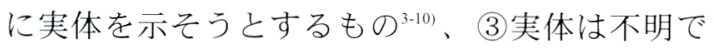
あるが、現象や臨床面から経絡を肯定するも の ${ }^{11-13)}$ などがある。「経絡とは何か」、古典におけ る流注の解釈から見てみると、「霊枢」本蔵篇に 「経脈は血気を行わして、陰陽を営ましめ、筋骨 を濡し、関節を利する所以のものなり」と記され ている。間中 ${ }^{15}$ は『鍼術における経絡は一種の循 環系であり、「気血営衛」という、人体の機能・ 生存に必要な要素がそのうちを流通し、これによっ て臟器も組織も養われ活動が維持されている』と 説き、この概念は起源にさかのぼって古代の中国 人が、『どういう現象をみて、あるいはどういう 臨床的絟験から経絡という概念に到達したのか。 また、経絡が「もの」なのか「機能系として考え るべきもの」なのかも検討を要する』としている。 何 ${ }^{15}$ は「今日まで、人体の構造や機能について知 られていることは、未だきわめて不十分なもので あり、経絡の実質を明らかにすることは、人体の 機能調節の法則をさらに深く認識する上で非常に 大切な意味を持っている」と説く。中国でも経絡
の実体については、やはり、これが鍼众醫學の源 泉となるものであるがゆえに、徹底的に科学的な メスを入れているとの記載も見られる。日本の鍼 众界においても、米山が投げかけた「経絡否定 論」の賛否両論をめぐって経絡の認否の論争が繰 り広げられた、いわゆる「経絡論争」といわれる 期（1952年2月から 1953 年6月）もあった。その 後も経絡・経穴の概念を科学的に実証しようとし て、機能的な面からの把握や形態的な面からの実 証を目指して多くの研究・報告がなされているが、 未だ経絡・経穴の本質を突く解明は出来ず、確証 の無きまま現在に至っている。以下にその研究・ 報告の主たるものをまとめる。

1）機能的に把握しようとする立場からは、長 浜 ${ }^{11}$ の報告に「経絡敏感者に対する針の響きによ る観察」があり、身体の一点に刺鍼すると、いわ ゆる「ひびき」が経絡に非常によく一致するルー トでこれを訴えるという。北出 ${ }^{12,13)}$ ほか、中国・ 日本において循経感覚伝達現象：PSC (Propagated Sensation along Channels) と称し、経絡に 沿つて波及する特殊な感覚を系口として経絡の解 明を試みる報告などが見られる。また、山田 ${ }^{(4)}$ は 循経感伝現象は経絡類似走行するリンパ管の平滑 筋を、知覚神経の放出した神経伝達物質が刺激し て発現すると論証している。

2) 経絡、経穴を形態学的に実証しようとする立 場からは、人体の肉眼解剖学的な観察として山 田 $^{4.5)}$ 、畑本 ${ }^{6)}$ 、豊田》 ら他の報告が、また経穴の組 織学的な面からの研究として、堀田 ${ }^{81}$ 、倉林 ${ }^{9}$ 渡 $^{(0)}$ ら他、多数の報告がある。経絡における肉眼解剖 学的観察から畑本は、経絡は機能的に関連するい くつかの筋支配神経および皮神経が、身体の長軸 方向に屋根瓦状走向した一つの複合神経路系であ ると見なすことが出来るとし、山田は肺経の流注 については上腕では筋皮神経、前腕でば外側前腕 皮神経、腕関節より母指末端までは橈骨神経浅枝 が相当し、これらの神経が次々と繊維を替えて肺 経の経絡をなしているものと推測するとし、同様 の見解を示している。豊田は神経や血管の走行、 および筋 (筋膜) などと、かなり密接な関連性が あることが解つたと報告している。組織学的な研 究では、倉林はツボと称される部位において、イ 
ヌ、ネコ、ウサギ、マウス、ラットにおいて 100 \%の割合で神経線維が存在し、渡はマウスを用い、 少なくとも神経線維と血管、リンパ管の複合体が 関係していることが判明したと報告している。一 方、堀田は皮膚の組織学的構造と経穴との関係に おいて、いわゆる経穴（つぼ）に該当するような 特殊な構造は見いだされなかったとしている。今 回、筋との相関は検討していないが、芹沢 ${ }^{17)}$ は人 体を構成する筋群のうち、浅層筋群は体幹・体肢 を問わず大部分が縦走筋であり、中層筋群は斜走 し、深層筋群は輪状（横走）筋層を形づくるが人 体の浅層縦走筋群の筋溝を体幹・体肢にわたり連 ねると経絡系統の経路とほぼ一致し、しかも結合 織系のよく発達した部分に該当すると、経絡を筋 との関係で述べている。

\section{（2）経絡走行と類似した解剖構造について}

前述のごとく、形態学的アプローチとしての経 穴部における組織学的研究はしばしば散見する。

しかし、経絡走行における肉眼解剖学的研究は、

一部の経絡 ${ }^{1-3)}$ では報告されているものの、全身に わたっての報告は少ない。今回、ほぼ全身の体表 を走行する経絡に着目し、経絡走行と類似した解 剖構造について部位別に検討した。

1)頭部を走行する経絡には、督脈経・膀胱経・ 胆経の三経がみられる。関係する解剖構造として 前頭部では、三叉神経第一枝 (眼神経) の枝であ る滑車上神経や眼窩上神経、および眼窩上動脈が あげられる。側頭部では、三叉神経の枝である煩 骨神経の煩骨顔面枝と㚘具側頭枝、耳介側頭神経、 および顔面神経の側頭枝があげられ、後頭部では 大後頭神経（第2䪿神経の後枝）や後頭動脈、お よび小後頭神経があげられる。外眼角の瞳子髎か ら側頭部を過ぎ、乳様突起後方の完骨に至り、次 いで前頭部に向かい、再び後頭部に至る胆経の走 行は、まさにこれら神経の走行を合わせた図に類

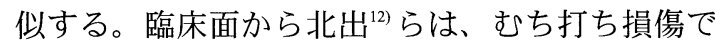
よく見られるGOTS (greater occipital trigeminal syndrome）つまり第2頝神経に障害があって後頝 部から大後頭神経領域に疼痛があると、三叉神経 第 I 枝にも痛みがよく出ることを述べ、この現象 は経絡の走行でよく理解出来るとしている。
2)顔面には大腸経・小腸経・三焦経・胃経・膀 胱経・胆経の手足の三陽経が走行するが、手の陽 明大腸経と足の陽明胃経がその主たるものである。 顔面に分布する動脈は舌骨の高さで総頝動脈から 分岐した外頝動脈の枝で、耳介前方を走行する浅 側頭動脈と下顎角前方より現れる顔面動脈が顔面 に分布する。これらの動脈の様相はまさに胃経の 走行に類似する。顔面動脈はさらに下唇動脈・上 唇動脈・眼角動脈に分岐する。大腸経から胃経へ の経絡の接続において、十四経発揮の記載では、 大腸経は「口を挟みて人中に交わり、左は右に之 き、右は左に之き、上がって鼻孔の迎香を挟む」 とされ、迎香より上行して両目中央の鼻根部で再 び左右相交叉し、睛明を経て眼窩下縁中央の四白 から胃経に連絡される。両側の上唇動脈と眼角動 脈をうまくたどることでこの経脈の走行と同様の 経絡を描くことが可能である。

3）上腕内側から前腕屈側、および手掌にかけて 走行する経絡は手の三陰経であり、外側（橈側） から手の太陰肺経、手の劂陰心包経、手の少陰心 経が該当する。いずれの経絡の走行も、腕神経叢 （C5～Th1）から構成される神経の走行に類似す る。同部位での肉眼解剖としては山田 ${ }^{4,5)}$ 、畑本 ${ }^{6}$ 、 豊田”らの報告もある。腕神経叢より外側神経束 を経て構成された筋皮神経は、腋窩で烏口腕筋を 貫き、上腕二頭筋と上腕筋との間を通つて时窝 の上腕二頭筋腱橈側に至る。この様相は手の太陰 肺経の走行に類似する。山田は筋皮神経の上腕二 頭筋の長頭への主筋枝を出す部位が肺経の経穴で ある天府（LU3）に、短頭への主筋枝を出す部位 が侠白（LU4）に相当すると記している。时窩の 上腕二頭筋腱橈側に至った筋皮神経は、外側前腕 皮神経として前腕橈側に分布する。前腕で肺経に 類似するものとして橈骨神経の浅枝があげられる。 腕橈骨筋の直下を橈骨動・静脈とともに母指に至 るまで走行する。内側・外側の神経束より構成さ れた正中神経は上腕動・静脈に伴い、上腕二頭筋 の内縁下部を通って肘窩に至り、円回内筋を貫き 前腕前面中央を走行して手掌の大陵 (PC7) ・ 労 宮（PC 8）に至る。正中神経の走行は手の劂陰心 包経にほぼ一致する。内側神経束を経て構成され た尺骨神経は上腕三頭筋の内側上縁を通り、上腕 
骨内側上顆のすぐ後の小海（SI8）を走行する。 小海は手の太陽小腸経に属し、この部位でのみ走 行の不一致を見るが、小海に至る直前また直後の 手掌の労宮に至るまでの手の少陰心経の走行は尺 骨神経の走行に類似する。前腕伸側を通る経絡は 手の三陽経と呼ばれ、橈側に手の陽明大腸経、中 央に手の少陽三焦経、尺側に手の太陽小腸経が該 当する。これら三陽経の走行下にある前腕伸側の 筋は、すべて橈骨神経の支配を受け、三陽経とも に同神経が関与している。豊田》は手の三陰経の 経絡の走行は太い神経・血管の走行に一致してい たが、手の三陽経ではこの事実は認められなかっ たと記している。我々も同様の所見を得ているが 各前腕皮神経分布に個体差はあると思われるもの の、各皮神経の経路と手の三陽経の走行との関係 は強いと思われる。また、経絡の接続において、 手の太陰肺経の列缺（肺経の絡穴）から、示指橈 側末端の商陽に向けて走行する手の陽明大腸経へ の絡脈の様相には、橈骨神経浅枝の手背での走行 に類似するものが見られる。この見解も山田と一 致する。

4)胸部を走行する経絡には前正中線上に任脈経、 順次外側に足の少陰腎経、足の陽明胃経、手の厥 陰心包経、足の太陰脾経などがある。各肋間で肋 間神経の前皮枝と外側皮枝を見ることが出来る。

横方向に走行するこれらの神経に対し、縦方向に 流れる経絡走行との間に違いは見られるが、各肋 間に存在する経穴はこれらの神経上に位置してお り、反応点として出現した部位を縦に連結すれば、 経絡に似た走行を見ることが出来る。

5)腹部を走行する経絡には前正中線上に任脈経、 順次外側に足の少陰腎経、足の陽明胃経、足の太 陰脾経、足の劂陰肝経、足の少陽胆経がある。肋 間神経前皮枝が腹直筋を貫いて皮下に現れる部位 および同皮神経の走行上に各経穴の部位がほぼ該 当しており、胸部同様、反応点として出現した部 位を縦に連結すれば経絡に似た走行は考えられる。 また、経絡が縦走することを重視するならば、腹 部の皮下組織中を縦走する浅腹壁動脈・静脈、お よび腹直笳下を縦走する上腹壁動脈・静脈および 下腹壁動脈・静脈などの解剖構造の関与も考えら れる。
6) 背部では後正中線上を督脈経が上行し、その 外方を足の太陽膀胱経の一行線と二行線が縦走す る。胸椎棘突起の際および外方から横走する胸神 経の後枝が見られる。縦方向に流れる経絡走行に 対し、横方向に走行する後枝との間に違いは見ら れるが、膀胱経の各経穴はこれらの神経上にほぼ 位置しており、反応点として出現した部位を縦に 連結すれば、経絡に似た走行を考えることは可能 で、同枝の皮下での走行と経穴部位との間に深い 関連が伺える。山田 ${ }^{4}$ によると膀胱経第一行線上 の背部俞穴は、胸神経後枝の外側枝が各肋間にお いて最長筋に筋枝を出している部位とほぼ相応し、 また膀胱経第二行線上の経穴と、正中より約 $6 \mathrm{~cm}$ で立ち上がる神経・血管が各胁間において腸肋 筋に筋枝を出している部位がほぼ相応していると の報告がある。また、経絡が縦走することを重視 するならば、僧帽筋の裏面を縦走する副神経 ・ 頝横動・静脈の走行が、足の太陽膀胱経の二行線 に一致する。また、僧帽筋の下層に見られる大・ 小菱形筋の裏面を走行する肩甲背神経および頚横 動・静脈深枝も膀胱経二行線の深部を縦走してい る。

7) 大腿前面を走行する経絡には足の陽明胃経、 足の太陰脾経、足の劂陰肝経があり、外側大腿皮 神経、大腿神経前皮枝、大腿神経前皮枝や大伏在 静脈の走行がそれぞれ類似する。

また、殿部と大腿後面では足の太陽膀胱経の第 一行線と第二行線が走行し、膝窩中央の委中穴で 合流する。仙骨神経叢から構成される坐骨神経の 走行、および脛骨神経と総腓骨神経への分岐に至 る経路がこの様相に類似する。

8）下腿内側を走行する経絡は足の三陰経と呼ば れ、足の太陰脾経、足の厥陰肝経、足の少陰腎経 が該当する。母指内側の末端から内果の前を通り、 脛骨の後縁骨際を上行する足の太陰脾経と大伏在 静脈の走行に類似性が見られ、脛骨内側面上を上 行する足の劂陰肝経は、下腿部上半で脾経を横切 る様が、伏在神経が大伏在静脈を越える様に類似 している。もし先達が体表における現象を優先し て経絡走行を考案していたのであれば、同部のみ 下腿部の表裏関係が崩れている理由として興味深 く理解出来る。足の少陰腎経は内果と踵骨の間の 
足根管を通過し、同部位で折り重なるように走行 する。足根管には脛骨神経や後脛骨動・静脈が見 られ、足底から内果後方を巡る足の少陰腎経にそ の走行が類似する。下腿前面、外側および後面を 走行する経絡は足の三陽経と呼ばれ、足の陽明胃 経、足の少陽胆経、足の太陽膀胱経が該当する。 総腓骨神経が腓骨頭の直下で浅腓骨神経と深腓骨 神経に分岐し、深腓骨神経と前脛骨動・静脈が下 腿骨間膜上を下行し足関節前面を経て足背部に達 する。この様相は足の陽明胃経に類似する。浅腓 骨神経は長腓骨筋の起始部を貫き、長・短腓骨筋 の間を下走し下腿の下半で皮下に出て外果の前方 を通り足背部に分布する。この走行は足の少陽胆 経に類似する。また、足の太陽膀胱経は脛骨神経 から分枝する内側腓腹皮神経と小伏在静脈の走行 に類似する。下腿下半では、足の太陽膀胱経は総 腓骨神経から分枝する外側腓腹皮神経と内側腓腹 皮神経が合して出来る腓腹神経が、小伏在静脈と 伴行して外果後方に向かう様相に類似する。

9) 足部外側では足の少陽胆経と足の太陽膀胱経 が走行する。足の少陽胆経は浅腓骨神経の走行に、 足の太陽膀胱経は腓腹神経からの延長である外側 足背皮神経の走行にいずれも類似が伺える。

\section{5.結語}

今回、経絡走行と類似する解剖構造について肉 眼解剖学的に頭部から足部に至る種々の部位にお いて検討を行った。経絡の実在を明確に証明しえ る単独の解剖構造は見られなかつたが、種々の部 位で類似した走行を示す解剖構造（動脈・静脈・ 神経）を確認することが出来た。「機能あるとこ ろには必ず形態がある」という。経絡の実体につ いては、これが鍼众医学の源泉と考えられ、 EBMが問われる現代、徹底的に科学的なメスを 入れるのが今後の基本的態度と思われる。経絡の 実体が解き明かされ、東洋医学（鍼尒治療）が医 業類似行為でなく医学一般の場において位置づけ られる日が来ることを願いたい。

最後に、ご献体頂きました御霊に敬意を表し感 謝致しますと共に、大阪大学・白菊会の皆様に心 より厚くお礼申し上げます。

\section{II. 上肢経絡 - 経穴の肉眼解剖学的研究}

山田鑑照

上肢経絡・経穴の肉眼解剖学的研究として名古 屋市立大学医学部、豊田勝良元研究員の学位論 文》の概要を紹介し、次に山田の研究を報告する。

II - I .「上肢およびその周辺に位置する経絡・経 穴と人体構成要素との関連についての肉眼解剖学 的研究」(豊田勝良)

\section{1.はじめに}

経絡・経穴の実態を形態学的に明らかにする目 的で人体の肉眼解剖学的な観察を行い、上肢周辺 の経絡・経穴部位における神経、血管、筋などと の地理的な関係について比較検討を行つた。

\section{2. 方法}

解剖 2 遺体の上肢周辺の経穴に注射針を用いて 墨汁を皮下に注入し、沈着した墨を目印に浅層よ り深層へと解剖を進め神経、血管、リンパ管、筋、 腱、勒帯、骨等と経絡・経穴との相互位置関係を 観察した。

\section{3. 結果と考察}

(1) 上肢経絡の肉眼解剖学的特徵

肺経は表1、心包経は表2、心経は表 3 の通り であった。上肢他 3 経は省略。

(2) 上腕 3 陰経の解剖所見

肺経上の天府（LU3）、侠白（LU4）、尺沢（LU 5) 上に橈側皮静脈が走行し、媣層に筋皮神経が走 行していた。心包経上の天泉（PC2）、曲沢 (PC3)の深層に正中神経、表層に内側前腕皮神経 掌側枝が走行していた。心経上青霊（HT2）、少 海（HT3）の深層に尺骨神経、表層に内側前腕皮 神経尺側枝が走行していた（図24）。

(3) 前腕 3 陰経の解剖所見

肺経の尺沢（LU5）、孔最（LU6）、列缺（LU7）、 経渠（LU8）上に橈側皮静脈と外側前腕皮神経が 走行していた。心包経の曲沢、郄門（PC4）、間 使 (PC5)、内関 (PC6) 上に内側前腕皮神経掌側 枝が走行していた。心経の少海、霊道（HT4）、 
通里（HT 5）、陰郄（HT 6）上に内側前腕皮神経 尺側枝が走行していた（図25）。

(4) 孔最、列缺、郄門の位置に関する若干の知見

1) 孔最は臨床上、自発痛、圧痛、硬結部位に相 当するところとして橈骨神経深枝が回外筋の浅層 と深層の間を貫く部位が考えられた。この部位は

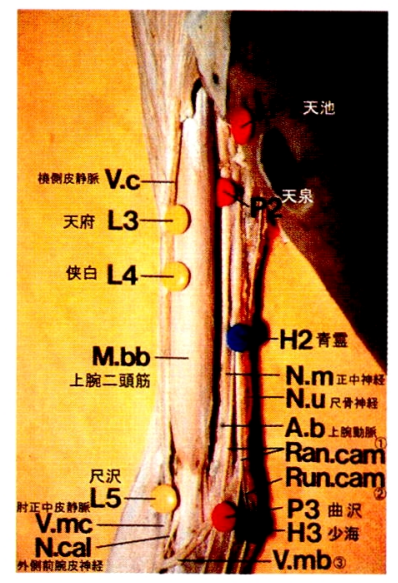

図24上腕 3 陰経の解剖所見

(1)内側前腕皮神経掌側枝

(2)内側前腕皮神経尺側枝

(3)尺側正中皮静脈
尺沢と太淵（LU9）間の尺沢寄り 1/6（約 $4 \mathrm{~cm} ）$ の位置となり、古典的記載と大きく離れるので孔 最之名付けた。

2) 列缺は臨床上、橈骨神経浅枝が腕橈骨筋腱の 下より皮下に出てくるところと思われた。この部 位は太淵と尺沢間で太淵寄り $1 / 3$ (約 $8.5 \mathrm{~cm})$ とな

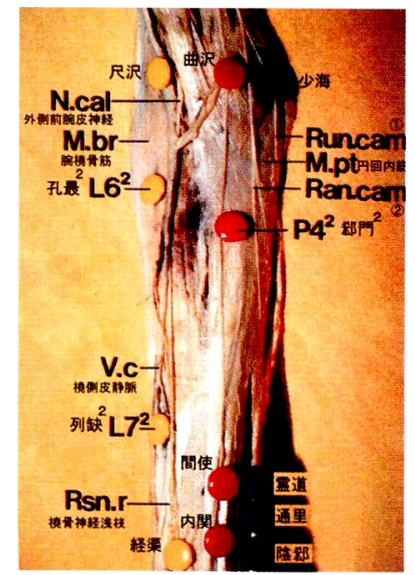

図 25 前腕 3 陰経の解剖所見

(1)内側前腕皮神経尺側枝 (2)内側前腕皮神経掌側枝

表 1. 太陰肺経（11経穴）の肉眼解剖学的特徵

\begin{tabular}{|c|c|c|c|c|c|c|}
\hline & 経穴名 & 皮神経 & 皮膚分節 & 神経 & 血管 & 備考 \\
\hline \multirow{6}{*}{$\begin{array}{l}\text { 1. 太い末梢神 } \\
\text { 経の走行上- } \\
\text { の部位 }\end{array}$} & 中府 & 中間鎖骨上神経 & $\mathrm{C}_{3}, \mathrm{C}_{4}$ & 外側神経束 & \multicolumn{2}{|c|}{ 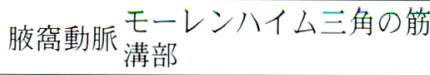 } \\
\hline & 雲門 & " & $" \prime$ & $\prime \prime$ & \multicolumn{2}{|l|}{$" \prime$} \\
\hline & 天府 & 上外側上腕皮神経 & $\mathrm{C}_{5}, \mathrm{C}_{6}$ & \multirow[t]{2}{*}{ 筋皮神経 } & & \\
\hline & & 下外側上腕皮神経 & $\mathrm{C}_{5}, \mathrm{C}_{6}$ & & & \\
\hline & 侠白 & 下外側上腕皮神経 & " & $"$ & & \\
\hline & 尺沢 & 外側前腕皮神経 & $\mathrm{C}_{5}, \mathrm{C}_{6}$ & 橈骨神経幹 & & \\
\hline $\begin{array}{l}\text { 5. 神経が筋膜 } \\
\text { を貫いて筋 } \\
\text { 層に入る部 } \\
\text { 位 }\end{array}$ & 孔最 & 外側前腕皮神経 & $\mathrm{C}_{5}, \mathrm{C}_{6}$ & 橈骨神経深枝 & & $\begin{array}{l}\text { 橈骨神経深枝が回外筋の } \\
\text { 浅層と深層の間を貫く部 } \\
\text { 位にほぼ一致している。 }\end{array}$ \\
\hline \multirow{2}{*}{$\begin{array}{l}\text { 6. 太い血管の } \\
\text { 走行上の部 } \\
\text { 位 }\end{array}$} & 経渠 & 外側前腕皮神経 & $\mathrm{C}_{5}, \mathrm{C}_{6}$ & \multicolumn{2}{|c|}{ 橈骨神経浅枝 橈骨動脈 } & \\
\hline & 太淵 & $"$ & " & $"$ & " & $\begin{array}{l}\text { 橈骨動脈拍動の触知に最 } \\
\text { も適した部位 }\end{array}$ \\
\hline $\begin{array}{l}\text { 7. 未梢神経が } \\
\text { 分岐する部 } \\
\text { 位 }\end{array}$ & 列缺 & 外側前腕皮神経 & $\mathrm{C}_{5}, \mathrm{C}_{6}$ & 橈骨神経浅枝 & & $\begin{array}{l}\text { 橈骨神経浅枝が腕橈骨笳 } \\
\text { 腱の下よ皮の出て手 } \\
\text { 背側と母指側に分岐する } \\
\text { 部位にほぼ一致する }\end{array}$ \\
\hline \multirow[t]{2}{*}{ 10. その他 } & 魚際 & 橈骨神経浅枝 & \multicolumn{2}{|l|}{$\mathrm{C}_{5}, \mathrm{C}_{6}$} & & \\
\hline & 少商 & 外側固有掌側指神経 & $\mathrm{C}_{6}$ & & & \\
\hline
\end{tabular}

註：部位分類は表 4 に準拠 
表 2. 厥陰心包経 (9経穴) の肉眼解剖学的特徵

\begin{tabular}{|c|c|c|c|c|c|c|}
\hline & 経穴名 & 皮神経 & 皮膚分節 & 神経 & 血管 & 備考 \\
\hline \multirow{3}{*}{$\begin{array}{l}\text { 1. 太い末梢神 } \\
\text { 経の走行上 } \\
\text { の部位 }\end{array}$} & 天泉 & 内側上腕皮神経 & $\mathrm{C}_{8}, \mathrm{Th}_{1}$ & 正中神経幹 & 上腕動脈幹 & \\
\hline & 曲沢 & 内側前腕皮神経掌側枝 & $\mathrm{C}_{8}, \mathrm{Th}_{1}$ & 正中神経幹 & $"$ & $\begin{array}{l}\text { 上腕動脈拍動の触知に } \\
\text { 最も適した部位 }\end{array}$ \\
\hline & 大陵 & 正中神経掌枝 & $\mathrm{C}_{8}, \mathrm{Th}_{1}$ & 正中神経幹 & & \\
\hline $\begin{array}{l}\text { 2. 神経が深層 } \\
\text { より浅層に } \\
\text { 出てくる部 } \\
\text { 位 }\end{array}$ & 間使 & 内側前腕皮神経掌側枝 & $\mathrm{C}_{8}, \mathrm{Th}_{1}$ & 正中神経幹 & & $\begin{array}{l}\text { 正中神経幹が橈側手根 } \\
\text { 屈筋腱と長掌筋腱との } \\
\text { 間で深層より浅層に出 } \\
\text { てくる部位 }\end{array}$ \\
\hline $\begin{array}{l}\text { 3. 皮神経が深 } \\
\text { 筋膜を貫い } \\
\text { て皮下に出 } \\
\text { てくる部位 }\end{array}$ & 内関 & $\begin{array}{l}\text { 内側前腕皮神経掌側枝 } \\
\text { 正中神経掌枝 }\end{array}$ & $\begin{array}{l}\mathrm{C}_{8}, \mathrm{Th}_{1} \\
\mathrm{C}_{8}, \mathrm{Th}_{1}\end{array}$ & 正中神経幹 & & $\begin{array}{l}\text { 正中神経掌枝が正中神 } \\
\text { 経幹より分岐し皮下に } \\
\text { 出てくる部位 }\end{array}$ \\
\hline $\begin{array}{l}\text { 5. 神経が筋膜 } \\
\text { を貫いて筋 } \\
\text { 層に入る部 } \\
\text { 位 }\end{array}$ & 郄門 & 内側前腕皮神経掌側枝 & $\mathrm{C}_{8}, \mathrm{Th}_{1}$ & 正中神経幹 & & $\begin{array}{l}\text { 正中神経幹が円回内筋 } \\
\text { の二頭間を貫き浅指屈 } \\
\text { 筋の起始腱の下へ入る } \\
\text { 部位 }\end{array}$ \\
\hline \multirow[t]{3}{*}{ 10. その他 } & 天池 & 第4肋間神経外側皮枝 & $\mathrm{Th}_{4}$ & & & \\
\hline & 労宮 & 正中神経掌枝 & $\mathrm{C}_{7}$ & & & \\
\hline & 中衝 & 外側第3 指掌側指神経 & $\mathrm{C}_{7}$ & & & \\
\hline
\end{tabular}

註：部位分類は表 4 に準拠

表 3. 少陰心経 (9経穴) の肉眼解剖学的特徵

\begin{tabular}{|c|c|c|c|c|c|c|}
\hline & 経穴名 & 皮神経 & 皮膚分節 & 神経 & 血管 & 備考 \\
\hline \multirow{4}{*}{$\begin{array}{l}\text { 1. 太い末梢神 } \\
\text { 経の走行上_ } \\
\text { の部位 }\end{array}$} & 極泉 & $\begin{array}{l}\text { 肋間上腕神経 } \\
\text { 内側上腕皮神経 }\end{array}$ & $\mathrm{C}_{8}, \mathrm{Th}_{1 \sim 3}$ & 尺骨神経幹 & 腋窩動脈 & \\
\hline & 通里 & $\begin{array}{l}\text { 内側前腕皮神経掌側枝 } \\
\text { 尺骨神経掌皮枝 }\end{array}$ & $\begin{array}{l}\mathrm{C}_{8}, \mathrm{Th}_{1} \\
\mathrm{C}_{8}, \mathrm{Th}_{1}\end{array}$ & $"$ & 尺骨動脈 & \\
\hline & 陰郄 & $\begin{array}{l}\text { 内側前腕皮神経掌側枝 } \\
\text { 尺骨神経掌皮枝 }\end{array}$ & $\begin{array}{l}\mathrm{C}_{8}, \mathrm{Th}_{1} \\
\mathrm{C}_{8}, \mathrm{Th}_{1}\end{array}$ & $"$ & $" \prime$ & $\begin{array}{l}\text { 尺骨動脈拍動の触知 } \\
\text { に最も適した部位 } \\
\end{array}$ \\
\hline & 神門 & $\begin{array}{l}\text { 内側前腕皮神経掌側枝 } \\
\text { 尺骨神経掌皮枝 }\end{array}$ & $\begin{array}{l}\mathrm{C}_{8}, \mathrm{Th}_{1} \\
\mathrm{C}_{8}, \mathrm{Th}_{1}\end{array}$ & $"$ & $"$ & \\
\hline $\begin{array}{l}\text { 3. 皮神経が深 } \\
\text { 筋膜を貫い } \\
\text { て皮下に出 } \\
\text { てくる部位 } \\
\text { て }\end{array}$ & 青霊 & $\begin{array}{l}\text { 内側上腕皮神経 } \\
\text { 内側前腕皮神経幹 }\end{array}$ & $\begin{array}{l}\mathrm{C}_{8}, \mathrm{Th}_{1} \\
\mathrm{C}_{8}, \mathrm{Th}_{1}\end{array}$ & 尺骨神経幹 & & $\begin{array}{l}\text { 内側前腕皮神経が } \\
\text { 内側上腕筋間中隔 } \\
\text { を貫いて皮下に出 } \\
\text { てる部位 }\end{array}$ \\
\hline $\begin{array}{l}\text { 7. 未梢神経が } \\
\text { 分岐する部 } \\
\text { 位 }\end{array}$ & 霊道 & $\begin{array}{l}\text { 内側前腕皮神経掌側枝 } \\
\text { 尺骨神経掌皮枝 }\end{array}$ & $\begin{array}{l}\mathrm{C}_{8}, \mathrm{Th}_{1} \\
\mathrm{C}_{8}, \mathrm{Th}_{1}\end{array}$ & 尺骨神経幹 & 尺骨動脈 & $\begin{array}{l}\text { 尺骨神経幹より尺 } \\
\text { 骨神経手背枝が分 } \\
\text { 岐する部位 }\end{array}$ \\
\hline
\end{tabular}

\footnotetext{
8. 勒帯・腱 - 少海 内側前腕皮神経尺側枝 $\mathrm{C}_{8}, \mathrm{Th}_{1}$ 関節包の部 位
}

\begin{tabular}{|c|c|c|c|c|c|}
\hline \multirow[t]{2}{*}{ 10. その他 } & 少府 & 尺骨神経掌皮枝 & $\mathrm{C}_{8}, \mathrm{Th}_{1}$ & $\begin{array}{l}\text { 尺骨神経掌枝 } \\
\text { の浅枝 }\end{array}$ & 総掌側指動脈 \\
\hline & 少衝 & 外側第 5 指掌側指神経 & $\mathrm{C}_{8}$ & & $\begin{array}{l}\text { 橈側第 } 5 \text { 指 } \\
\text { 掌側指動脈 }\end{array}$ \\
\hline
\end{tabular}

註：部位分類は表 4 に準拠 
る。これを列缺 と名付けた。

3) 郄門は臨床上、正中神経幹が円回内筋の二頭 （上腕頭と尺骨頭）間を通り、浅指屈筋の起始腱 の下を通る部位と思われた。この位置は曲沢と大 陵（PC 7）間の曲沢寄り $1 / 3 （$ 約 $8 \mathrm{~cm}$ ） となる。 これを郄門と名付けた。

(5) 上肢 6 経 91 穴の解剖学的特徵

上肢の肉眼解剖学的に確認できる神経との関連 が深い経穴は 91 穴中 38 穴。太い血管の走行上の 部位にある経穴が 8 穴。肉眼解剖学的に観察でき る神経・血管の関連の深い経穴は 91 穴中 46 穴と なり神経・血管と経穴との肉眼解剖学的関連は密 接なものがあるといえる（表4）。

(6)その他

経絡・経穴と筋分節、鍼众刺激と春髄分節およ び反射弓、鍼众刺激と自律神経との関係について 考察した。

\section{4. 結語}

上肢およびその周辺に位置する各経絡・経穴は 人体構成要素（神経、血管、筋、筋膜、腱、勒帯、 骨等）との関連性では神経や血管の走行および筋 （筋膜）などと、かなり密接な関連性が認められ 特徵ある部位であることが判明した。
II - II . 上肢経絡・経穴と皮神経・血管との関係 について（山田鑑照）

1.はじめに

経絡治療において切皮程度の刺鍼で経絡の調整 を行っているとされる。その切皮程度の刺鍼で刺 激できる皮下の皮神経・血管の走行と経絡の走行 が如何なる関係にあるか明らかにすることを目的 としてヒト皮膚の解剖をして検討した。

\section{2. 方法}

名古屋市立大医学部において献体遺体の上肢経 絡・経穴相当部の皮膚と皮神経・血管の位置関係 を損傷しないように解剖し、この部位における神 経・血管の走行と経絡・経穴との関係を観察した。

\section{3. 結果と考察}

(1)肺経における神経・血管の走行

肺経（図 26） は上肢の深層を筋皮神経が走行 し、表層は橈側皮静脈が走行していた。前腕では 外側前腕皮神経と橈側皮静脈が伴走し、列缺付近 から橈骨神経浅枝がこれに加わり、手では橈側皮 静脈と橈骨神経浅枝が肺経に走行していた。尺沢 で外側前腕皮神経が皮膚と密接していた。孔最の 前後で外側前腕皮神経と橈側皮静脈が走行してい た（図 27）。

表 4. 上肢の 3 陰経、 3 陽経の 6 経絡上に位置する 91 経穴についての肉眼解剖学的特徵

\begin{tabular}{|c|c|c|c|c|c|c|c|}
\hline $\begin{array}{ll}\text { 経穴 } & \text { 経絡名 } \\
\text { 部位の肉眼 } \\
\text { 解剖学的特徵 }\end{array}$ & 肺経 & 心包経 & 心経 & 大腸経 & 三焦経 & 小腸経 & 小計 \\
\hline 1. 太い末梢神経の走行上の部位 & 5 & 3 & 4 & 4 & 7 & 4 & 27 \\
\hline 2. 神経が深層より浅層に出てくる部位 & & 1 & & & & & 1 \\
\hline 3. 皮神経が深筋膜を貫いて皮下に出てくる部位 & & 1 & 1 & & 1 & & 3 \\
\hline 4. 神経が骨孔より出てくる部位 & & & & & 1 & & 1 \\
\hline 5. 神経が筋膜を貫いて筋層に入る部位 & 1 & 1 & & & 1 & 1 & 4 \\
\hline 6. 太い血管の走行上の部位 & 2 & & & 1 & 2 & 3 & 8 \\
\hline 7. 末梢神経が分岐する部位 & 1 & & 1 & & & & 2 \\
\hline 8. 勒帯・腱・関節包の部位 & & & 1 & 5 & 3 & 2 & 11 \\
\hline 9. 骨縫線の線上の部位 & & & & & & & 0 \\
\hline 10. その他 & 2 & 3 & 2 & 10 & 8 & 9 & 34 \\
\hline 計 & 11 & 9 & 9 & 20 & 23 & 19 & 91 \\
\hline
\end{tabular}




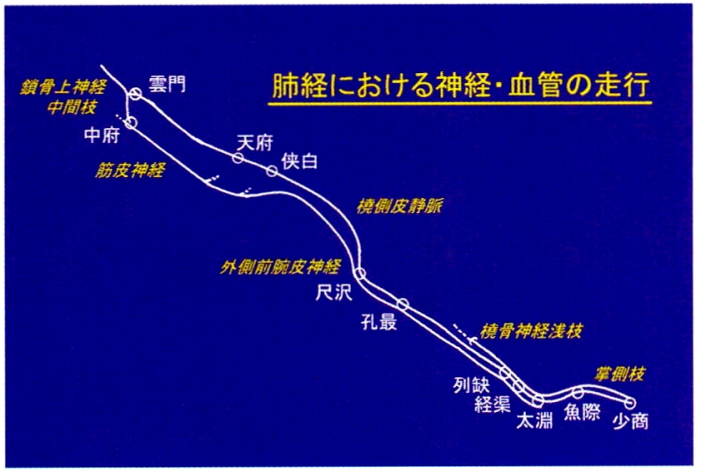

図26 肺経における神経・血管の走行

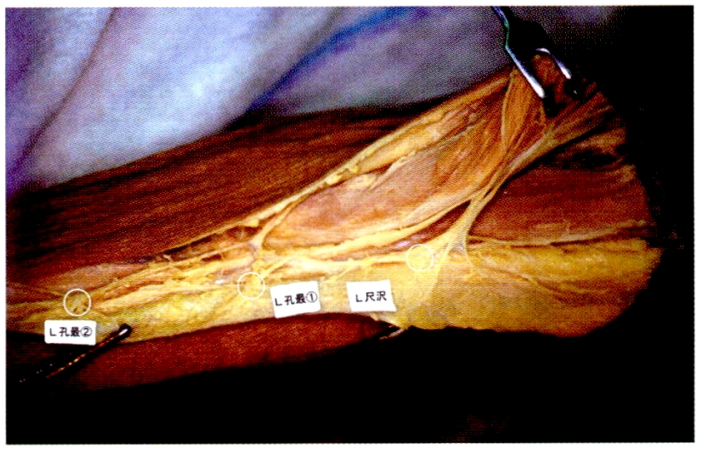

図27 尺沢、孔最相当部の皮下解剖所見

(2)心包経における神経・血管の走行

心包経（図 28）の天池（PC 1）には内側前腕皮 神経の枝とともに腋窩動脈の枝が来ていた。天泉 において内側前腕皮神経が尺側枝と前枝に分枝し ていた。天池（前胸部）と天泉（上腕部）には内 側前腕皮神経の本幹と分枝という表層の解剖学的 連続性があると考えられた。天泉で分枝した内側 前腕皮神経尺側枝は、内側前腕皮神経前枝上の曲 沢に枝を出していた（図29）。内側前腕皮神経前 枝は曲沢から労宮（PC 8) まで走行が確認された。 正中神経は深部を曲沢から中衝（PC9）まで走 行し、また正中神経は郄門、関使 - 内関 - 大陵 労宮に皮枝を出していた。特に労宮付近では神経 が2つの枝となって皮膚に貫入していた（図 30）。 (3) 心経における神経・血管の走行

心経（図 31）の極泉（HT1）には肋間上腕神 経が内側上腕皮神経に合流しており、これが前胸 部と上腕との深層の解剖学的連続性であると考え られた。極泉から青霊までは内側上腕皮神経、青 霊で内側前腕皮神経尺側枝が合流し、少海におい

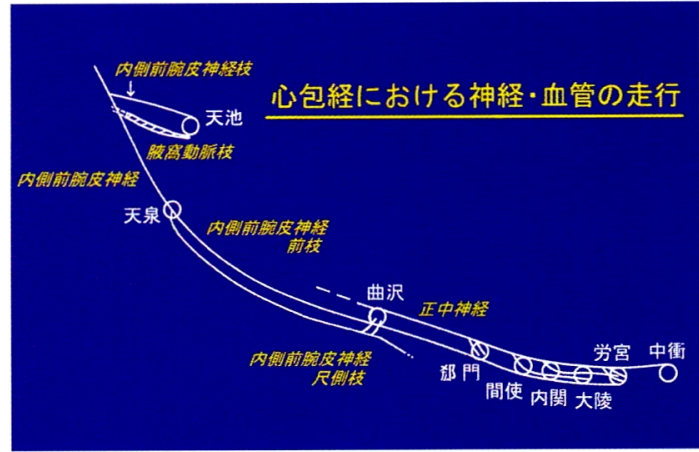

図28 心包経における神経・血管の走行

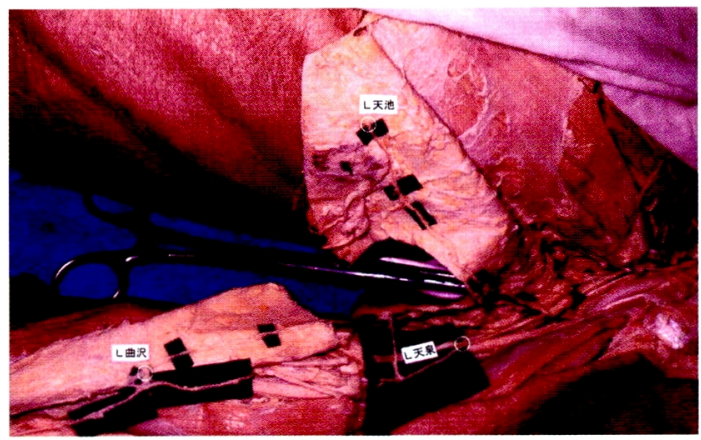

図 29 天池、天泉、曲沢相当部の解剖所見

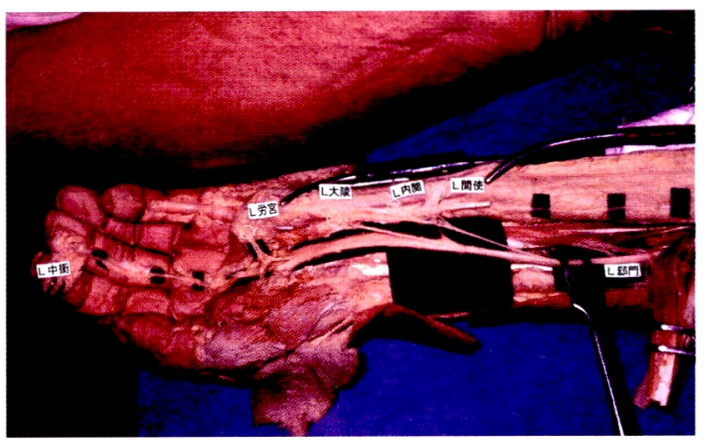

図 30 間使〜中衝相当部までの解剖所見

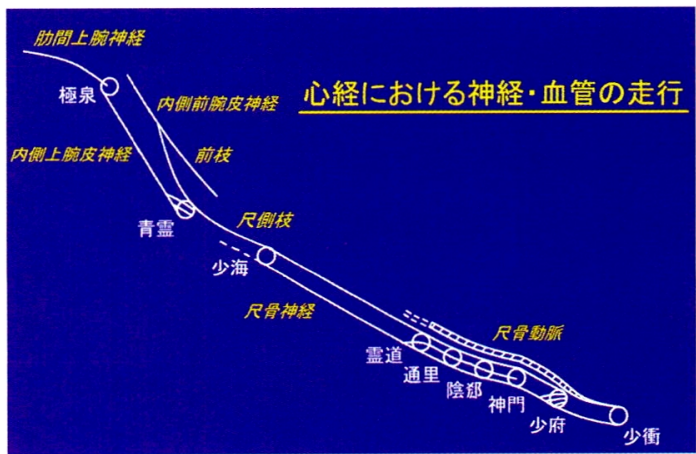

図31 心経における神経・血管の走行 
て内側前腕皮神経尺側枝と尺骨神経が合流して、 少府（HT 8）まで伴走する。霊道から少府まで尺骨 神経からの皮枝が走行し、また、尺骨動脈が伴走す る。

内側前腕皮神経尺側枝が走行しているところに尺 骨神経皮枝が走行している陰郄に尺骨神経皮枝と 尺骨動脈枝が来ていた。少府は尺骨神経皮枝と尺 骨動脈枝の数枝が皮下に貫入していた（図32）。

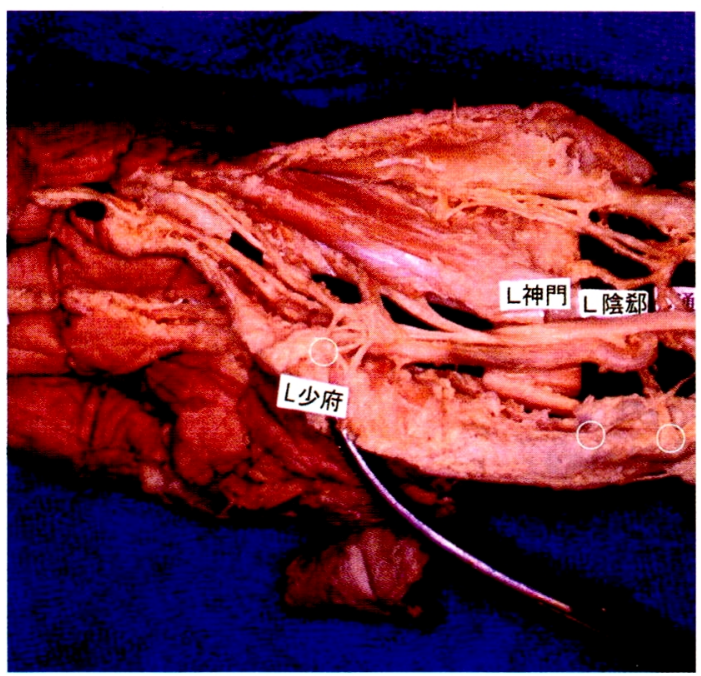

図 32 陰郄、神門、少府相当部の解剖所見

（4）小腸経の上腕之肩甲骨の連絡

腋窩動脈と肩甲上動脈が肩甲回旋動脈で吻合し ていた。肩甲回旋動脈は上腕と棘下窩を肉眼解剖 学的に連絡しており、小腸経の上腕部と棘下窩部 を結ぶ経絡走行を想起された。肩貞（SI9）を除 くすべての肩甲骨上の経穴は肩甲上神経と肩甲上 動脈の走行上に位置していることが肉眼解剖学的 に観察された。曲垣（SI 13）、肩外俞（SI 14）に は副神経の枝が来ており、肩外俞には肩甲背神経 も走行していた（図33）。

\section{4. 結語}

ヒト上肢皮膚の経絡・経穴相当部を解剖し、以 下の観察結果を得た。

（1）上肢経絡相当部には皮神経、動脈、皮静脈の 走行が確認された。経穴相当部では、これらの解 剖学的要素が皮膚に貫入するなどの皮膚と密接な 構造が観察された。また、経穴相当部の部位が左

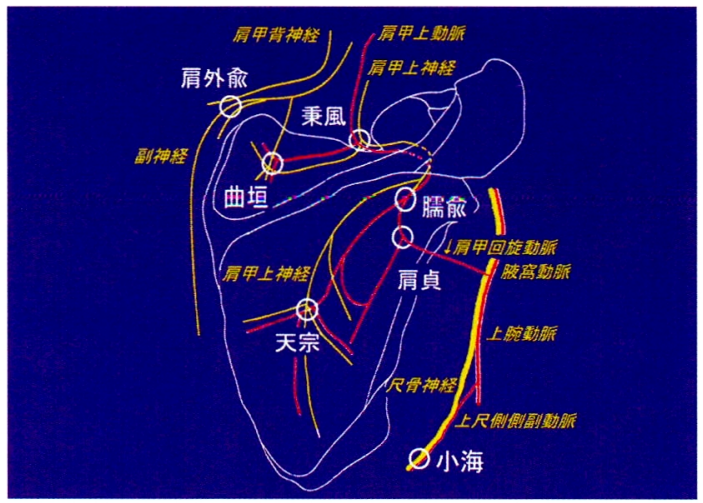

図33 小腸経小海〜肩外俞相当部の解剖所見

右において異なつたり、古典的な部位とは若干異 なることがしばしばみられた。

(2) 心包経・心経の前胸部之上腕之の経絡走行と 類似する神経・血管による肉眼解剖学的連続性が 観察された。また、小腸経の上腕之肩甲骨部への 経絡走行と類似する血管による肉眼解剖学的連続 性が観察された。

謝 辞

ご遺体を提供された御霊に敬意と感謝の意を表 すると共に、ご遺族、ならびに名古屋市立大学不 老会に心より深謝いたします。

\section{III. 中国における刺鍼安全深度の研究と進展状況}

王 財源

\section{1.はじめに}

鍼尒の臨床において、刺鍼深度の不注意により 重要な臓器を損傷させ、過誤を起こすことがある。 これらの刺鍼時において過誤をおこし易い経穴を 「危険経穴 (穴位) 」(1.19) と呼ばれている。今回は 中国における頭頝部、胸部、腹部の危険経穴の解剖 学的な刺銊安全深度と進展状況について報告する。

\section{2. 方法}

研究の情報提供者は上海中医薬大学解剖学教室、 㛜振国教授、張建華、顧洪川、毛根金、趙英侠、 余安勝のグループで、上海中医薬大学解剖教室の 合計 51 遺体（男性 21 遺体）（女性 30 遺体）を用 いた。経穴部位の位置決定は 1990年6月7日に政 
府が公表した「経穴部位の標準化」を指標とした。 胸部は少陰腎経、陽明胃経、劂陰肝経、少陽胆経、 㷧陰心包経、太陰脾経上の経穴を用い、腰背部で は太陽膀胱経、少陽胆経、太陽小腸経、少陽三焦 経上の経穴を用いた。

\section{3. 結果および考察}

（1）風府 (GV 16) と痖門 (GV 15) の刺鍼危険深度 風府は男性 21 例、 $53.11 \mathrm{~mm} \pm 7.95 \mathrm{~mm}$ 、女性 30 例、 $50.10 \mathrm{~mm} \pm .7 .93 \mathrm{~mm}$ となり、各々の平均値は接近し て統計学的な差異はない。これは男女間における 刺鍼危険深度が近似していることを示している。 しかし、癌門では男性が 21 例 $53.13 \mathrm{~mm} \pm 8.70 \mathrm{~mm}$ 、 女性 30 例、 $47.62 \mathrm{~mm} \pm 7.22 \mathrm{~mm}$ で、各々男女の平均 值間では有意な差異があった ${ }^{20)}$ 。

（2）風池（GV 20）と晴明（BL 1）の刺鍼危険深度 風池と晴明では男女を分けないで左側と右側の 統計学的処理を行った。その結果、風池 51 例で $49.71 \pm 9.14 \mathrm{~mm}$ 、右側では $50.23 \pm .9 .26 \mathrm{~mm}$ 、晴明 51 例では左側 $43.43 \pm 7.09 \mathrm{~mm}$ 、右側では $42.81 \pm 6.04$ $\mathrm{mm}$ となり、左右の差異は認められなかった ${ }^{20)}$ 。

（3）風池と晴明の男女別左右の測定結果

風池では男性の左側 $50.31 \pm 8.26 \mathrm{~mm}$ と右側 51.12 $\pm 8.43 \mathrm{~mm}$ 、女性の左側 $49.37 \pm 9.94 \mathrm{~mm}$ と右側 49.52 $\pm 9.98 \mathrm{~mm}$ 、また、晴明では男性の左側 $43.65 \pm 5.71$ $\mathrm{mm}$ と右側 $42.45 \pm 5.63 \mathrm{~mm}$ 、女性の左側 $43.28 \pm 8.11$ $\mathrm{mm}$ と右側 $43.09 \pm 7.04 \mathrm{~mm}$ であっ。風池、晴明両 穴の男女各々においても左右の刺鍼危険深度の平 均值は近く、有意な差は認められなかった。さら に風池、晴明の男女間における同一経穴の同一側 における平均值に関しても統計学的処理を行った が、男女間においても差異が認められなかった ${ }^{20)} 。$

そこで、刺鍼安全深度＝刺鍼危険深度の平均值 $\times 80 \%$ と仮定して刺鍼安全深度を求め、風府、痘 門、風池、晴明における刺鍼安全深度を検討した ところ、風府は男性 $42.49 \mathrm{~mm}$ 、女性 $40.08 \mathrm{~mm}$ 、 癋門は男性 $42.50 \mathrm{~mm}$ 、女性 $38.10 \mathrm{~mm}$ 、風池は男 性 $40.58 \mathrm{~mm}$ 、女性 $39.56 \mathrm{~mm}$ 、晴明で男性 $34.44 \mathrm{~m}$ $\mathrm{m}$ 、女性 $34.55 \mathrm{~mm}$ 以下であるとの結論を得た ${ }^{20)}$ 。

(4) 胸部と背部における刺鍼危険深度と刺鍼安全 深度

\section{1) 前胸部}

歩廊 (KI22)、神封（KI23）、霊墟（KI24）、
表 5. 胸部経穴の刺鍼危険深度 $(\chi \pm S D m m)$ と刺鍼安 全深度 $(\mathrm{mm})$ （厳振国らの資料による)

\begin{tabular}{|c|c|c|c|c|}
\hline & \multicolumn{2}{|c|}{ 刺鍼危険深度 } & \multicolumn{2}{|c|}{ 刺鍼安全深度 } \\
\hline 穴名 & 左側 & 右側 & 左側 & 右側 \\
\hline 俞府 & $26.75 \pm 6.03$ & $26.31 \pm 6.38$ & 18.73 & 18.42 \\
\hline 或中 & $14.31 \pm 6.18$ & $13.59 \pm 6.24$ & 10.02 & 9.51 \\
\hline 神蔵 & $12.11 \pm 7.21$ & $11.87 \pm 6.22$ & 8.47 & 8.31 \\
\hline 霊噓 & $13.08 \pm 5.11$ & $13.14 \pm 5.34$ & 9.16 & 9.20 \\
\hline 神封 & $15.44 \pm 5.41$ & $14.41 \pm 4.73$ & 10.81 & 10.09 \\
\hline 歩廊 & $17.64 \pm 5.75$ & $16.09 \pm 4.52$ & 12.35 & 11.26 \\
\hline 欠盆 & $38.34 \pm 12.45$ & $38.50 \pm 12.42$ & 26.84 & 26.95 \\
\hline 気戸 & $30.83 \pm 10.10$ & $30.62 \pm 11.21$ & 21.58 & 21.43 \\
\hline 庫房 & $19.76 \pm 8.96$ & $18.66 \pm 8.40$ & 13.83 & 13.06 \\
\hline 屋毉 & $16.35 \pm 8.49$ & $15.42 \pm 7.34$ & 11.45 & 10.79 \\
\hline 膺空 & $15.29 \pm 8.31$ & $14.74 \pm 7.60$ & 10.70 & 10.32 \\
\hline 乳根 & $12.21 \pm 4.96$ & $13.93 \pm 4.82$ & 8.55 & 9.75 \\
\hline 期門 & $12.81 \pm 5.12$ & $14.37 \pm 5.21$ & 8.97 & 10.06 \\
\hline 日月 & $15.19 \pm 4.18$ & $15.81 \pm 4.03$ & 10.63 & 11.07 \\
\hline 天池 & $15.48 \pm 9.68$ & $15.00 \pm 7.40$ & 10.84 & 10.50 \\
\hline 淵液 & $19.44 \pm 11.62$ & $19.64 \pm 11.00$ & 13.61 & 13.75 \\
\hline 大包 & $18.70 \pm 10.11$ & $18.19 \pm 7.13$ & 13.09 & 12.73 \\
\hline 輙筋 & $16.51 \pm 10.08$ & $16.50 \pm 9.38$ & 11.56 & 11.55 \\
\hline 周栄 & $24.74 \pm 9.32$ & $24.70 \pm 10.28$ & 17.32 & 17.29 \\
\hline 胸郷 & $20.12 \pm 9.00$ & $19.77 \pm 8.48$ & 14.08 & 13.83 \\
\hline 天谿 & $17.49 \pm 9.43$ & $17.26 \pm 8.41$ & 12.24 & 12.08 \\
\hline 食竇 & $15.17 \pm 9.30$ & $16.86 \pm 9.20$ & 11.80 & 11.80 \\
\hline & 男性 & 女性 & & \\
\hline 天突 & $22.91 \pm 7.97$ & $24.59 \pm 7.17$ & 16.04 & 17.21 \\
\hline
\end{tabular}

神蔵（KI 25）、庫房（ST 14）、屋毉（ST 15）、膺 空（ST 16）、膻中 (CV 17)、乳根 (ST 18)、天池 （PC1）、食竇（SP 17）、天笑（SP 18）の諸穴には $10 \mathrm{~mm}$ 以上刺鍼すると肺に達して気胸の発生する恐 れがある ${ }^{21)}$ (表5)。

\section{2) 側胸部}

大包 (SP 21)、淵腋 $(\mathrm{GV} 22)$ 、輙筋 $(\mathrm{GV} 23)$ も $10 \mathrm{~mm}$ 以上刺入すると気胸の恐れがある。皮膚 から肺までの距離は背部に比べて胸部が一層短い ため刺鍼深度には気を付けなくてはいけない。ま た、胸郷（SP 19）、周栄（SP 20）では皮膚から肺 までの距離はやや長い、平均 $20 \mathrm{~mm}$ 未満なら安全 深度と言われているが、一般的には $10 \mathrm{~mm}$ 以内が 適切である ${ }^{21)}$ (表5)。

3) 背部

膀胱経では上部の大杼（BL 11）、風門（BL 12）、 肺俞（BL 13）、劂陰俞（BL 14）、心俞 (BL 15)、 附分 (BL41)、魄戸 (BL 42)、膏肓 (BL 43)、神 
堂（BL 44）と、下部の脾俞（BL 20）、胃俞（BL 21）、意舎 (BL 49)、胃倉 (BL 50)、肓門 (BL 51)、 志室（BL 52）の刺鍼危険深度とその標準偏差は 比較的に大きい。しかし、中央部、督栯（BL 16）、 膈俞 (BL 17)、肝俞 (BL 18)、胆俞 (BL19)、譩 譆 (BL 45)、膈関 (BL 46)、魂門 (BL 47)，陽綱 （BL 48）の刺鍼深度とその標準偏差は小さく、そ れぞれの軟部組織の厚さの相違によるものである とされ、男女ともに第2側線の中央下部の膈関、 魂門、陽綱では軟部組織が薄く過誤を起こしやす (22) (表6)。

\section{風府穴刺鍼時の層次解剖}
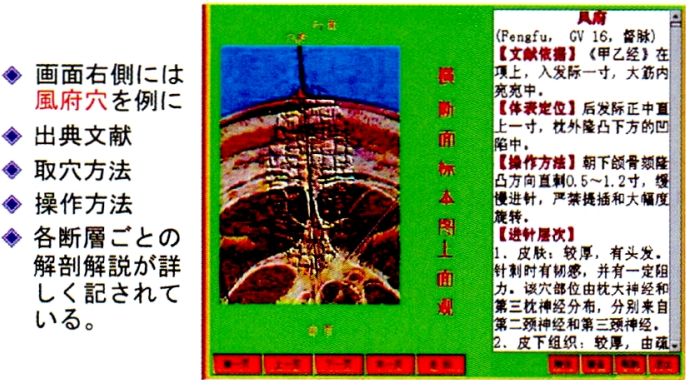

図34 初期の経穴 3Dソフトの開発

\section{立体人体可視経穴モデル（肩井穴）}

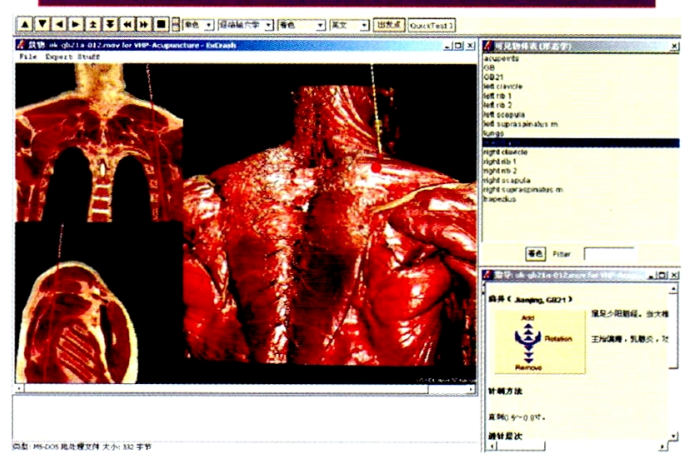

図 35 経穴可視ソフトのサンプル

\section{知能動画 (天突穴)}
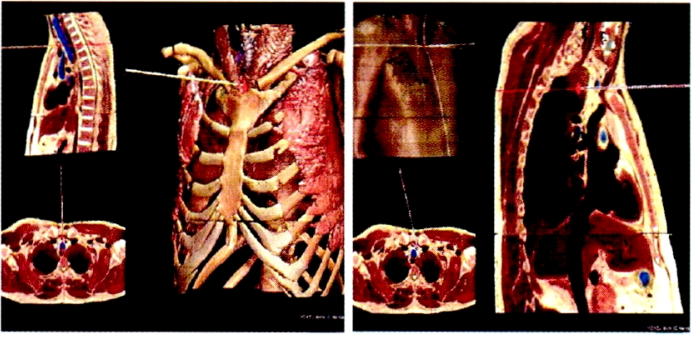

図 36 経穴をクリックすると画像の位置を移動すること ができる

表6. 背部経穴の刺鍼危険度数 $(\chi \pm S \mathrm{SDm})$ (厳振国らの資料による)

\begin{tabular}{|c|c|c|c|c|}
\hline & \multicolumn{2}{|c|}{ 男 性 } & \multicolumn{2}{|c|}{ 女 性 } \\
\hline 穴名 & 左側 & 右側 & 左側 & 右側 \\
\hline 大杼 & $65.98 \pm 13.07$ & $65.95 \pm 10.57$ & $62.37 \pm 11.61$ & $59.12 \pm 11.65$ \\
\hline 風門 & $62.45 \pm 12.78$ & $63.33 \pm 11.62$ & $57.65 \pm 10.85$ & $54.30 \pm 7.76$ \\
\hline 肺郩 & $54.53 \pm 12.92$ & $54.79 \pm 11.86$ & $46.67 \pm 8.86$ & $46.58 \pm 6.58$ \\
\hline 劂陰俞 & $44.25 \pm 11.41$ & $46.04 \pm 10.17$ & $40.25 \pm 9.37$ & $41.14 \pm 11.06$ \\
\hline 心骨 & $37.96 \pm 10.20$ & $42.01 \pm 10.44$ & $35.07 \pm 8.14$ & $37.91 \pm 10.34$ \\
\hline 督俞 & $33.32 \pm 9.10$ & $38.30 \pm 9.75$ & $32.28 \pm 7.25 ※$ & $36.40 \pm 12.45$ \\
\hline 隔俞 & $31.58 \pm 8.84 \%$ & $37.70 \pm 11.55$ & $29.78 \pm 7.81 ※$ & $34.53 \pm 11.66$ \\
\hline 膵翁 & $31.13 \pm 8.79 ※$ & $37.96 \pm 10.73$ & $30.40 \pm 7.68$ & $34.66 \pm 11.50$ \\
\hline 肝雬 & $32.57 \pm 9.63 \%$ & $38.56 \pm 9.47$ & $31.57 \pm 7.65$ & $34.11 \pm 11.72$ \\
\hline 胆䐘 & $35.94 \pm 11.79$ & $40.08 \pm 10.09$ & $35.52 \pm 9.58$ & $33.50 \pm 11.07$ \\
\hline 脾翁 & $39.02 \pm 12.98$ & $43.51 \pm 11.24$ & $37.62 \pm 10.13$ & $32.72 \pm 7.76$ \\
\hline 胃有 & $43.61 \pm 10.51$ & $49.16 \pm 11.30$ & $41.69 \pm 7.67$ & $40.25 \pm 11.01$ \\
\hline 肩外俞 & $55.69 \pm 14.95$ & $59.82 \pm 12.27$ & $55.15 \pm 13.23$ & $52.11 \pm 10.97$ \\
\hline 附分 & $54.44 \pm 11.36$ & $57.20 \pm 12.30$ & $51.21 \pm 11.34$ & $49.16 \pm 11.01$ \\
\hline 魄戸 & $46.41 \pm 11.55$ & $50.23 \pm 10.56$ & $42.43 \pm 11.07$ & $41.52 \pm 8.67$ \\
\hline 膏肓 & $36.70 \pm 11.00$ & $39.89 \pm 9.58$ & $35.69 \pm 11.59$ & $34.30 \pm 7.35$ \\
\hline 神堂 & $30.28 \pm 9.41$ & $31.25 \pm 9.09$ & $28.28 \pm 8.19$ & $27.53 \pm 7.11$ \\
\hline 譩譆 & $25.05 \pm 8.63$ & $25.87 \pm 8.71$ & $23.73 \pm 6.78$ & $21.42 \pm 5.97$ \\
\hline 隔関 & $21.23 \pm 7.74$ & $22.07 \pm 7.24$ & $20.58 \pm 5.54$ & $19.15 \pm 5.23$ \\
\hline 魂門 & $20.28 \pm 5.79$ & $20.82 \pm 4.85$ & $19.41 \pm 4.47$ & $18.54 \pm 3.87$ \\
\hline 陽綱 & $20.83 \pm 6.17$ & $22.35 \pm 6.22$ & $20.14 \pm 4.90$ & $18.92 \pm 3.68$ \\
\hline 意舎 & $23.41 \pm 8.07$ & $24.48 \pm 7.27$ & $22.00 \pm 6.28$ & $21.71 \pm 4.54$ \\
\hline 意倉 & $29.49 \pm 11.93$ & $30.21 \pm 10.97$ & $26.89 \pm 7.62$ & $26.74 \pm 7.06$ \\
\hline 肓門 & $33.61 \pm 15.16$ & $33.38 \pm 10.34$ & $33.38 \pm 11.66$ & $30.98 \pm 9.26$ \\
\hline 志室 & $32.12 \pm 11.43$ & $33.25 \pm 8.28$ & $34.67 \pm 7.33$ & $33.39 \pm 12.70$ \\
\hline 肩井 & $56.56 \pm 12.53$ & $59.52 \pm 9.88$ & $55.35 \pm 10.87$ & $55.19 \pm 11.61$ \\
\hline 天髎 & $62.24 \pm 14.34$ & $63.29 \pm 10.14$ & $58.53 \pm 12.03$ & $57.25 \pm 11.40$ \\
\hline 肩中公 & $61.11 \pm 14.73$ & $59.84 \pm 11.09$ & $57.79 \pm 12.15$ & $54.66 \pm 10.06$ \\
\hline
\end{tabular}

左右の有意差 $※(p<0.05)$ 
以上の資料より厳振国らのグループは新しい立 体経穴解剖構造ソフトを開発し（図 34）、さらに 白娟らのグループと共同 VHP（Visible Human Project）数值を指標とした立体人体可視経穴ソフ トを開発している（図35、図36）。このソフトは 断面解剖や層次解剖のみではなく、さらに動画、 体表解剖、取穴部位までの標示を可能としてい る23)。

\section{4. 結語}

前胸部の 22 経穴では左右差はない。天突 $(\mathrm{CV}$ 22）では男女間の差異はなかった。背腰部では男 女とも多くの経穴で左右差はない。膀胱経の背部 で上部、下部の刺鍼危険深度とその標準偏差は比 較的大きいが、中央部では小さい。膀胱経の同一 高さでの刺銊危険深度は第 1 側線より第 2 側線の 值は小さい。その結果、第2 側線の中央下部付近 （膈関、魂門、陽綱）が最も薄い。頭頸部では風 府で男性は $42.49 \mathrm{~mm}$ 、女性 $40.08 \mathrm{~mm}$ 、痦門では男性 は $42.50 \mathrm{~mm}$ 、女性 $38.10 \mathrm{~mm}$ 、風池では男性は 40.58 $\mathrm{mm}$ 、女性 $39.77 \mathrm{~mm}$ 、睛明では男性は $34.44 \mathrm{~mm}$ 、女性 $34.25 \mathrm{~mm}$ 以下であった。

\section{謝 辞}

今回の報告に対して本学会に資料を提供して頂 いた上海中医学大学解剖学教室、厳振国教授を初 めとする諸先生方に謝辞を申し上げます。

\section{IV. 経穴の刺鍼安全深度の研究を顧みて \\ 一日本と中国での安全深度との比較一 尾崎朋文、森 俊豪、吉田 篤 北村清一郎、米山 榮}

\section{1.はじめに}

医療現場では医療事故が発生しマスコミをにぎ わしている。これは鍼众においても対岸の火事で はない。鍼众での一つの医療事故が当事者や鍼众 界にとって計り知れない負の影響を生じる可能性 がある。今回、事故防止のため主要経穴の刺鍼の 安全深度について、遺体解剖所見や生体での画像 所見を用いマクロ解剖学的に長年研究してきたの
で報告する。また、主要経穴の刺鍼の安全深度に ついて、中国（厳振国）と日本（尾崎）での文献 による比較も行った。

\section{2. 方法}

安全深度の検討は遺体では大阪大学と徳島大学 両歯学部の実習用遺体を用いた。生体でのCT・ MRIの画像は主に川村病院 - 山田記念温泉病院 神経内科受診患者、X 線画像は本校健康学生・附 属鍼尒室患者より得た。画像上での計測、および 刺鍼後の体表上の鍼体長の計測から、刺入深度を 算出した。検討した主要経穴は痘門（GV15）・ 天柱 (BL 10) - 肩井 (GV 21) - 膏肓 (BL 43) - 膻 中（CV 17）とした。

3. 結果

(1) 痘門・天柱 ${ }^{24}$

図37左は皮膚、筋、および環椎〜第3頸椎の椎 弓を除去し、眉間中央（印堂）方向に刺入した癌 門（図 37-1）、および同側の眉頭の攅竹（BL2） 方向に刺入した天柱（図 37-2） と脊髄（図 37-3） や椎骨動脈（図37-4）との関係をみたものである。 癋門の印堂穴方向への刺入針は僧帽筋や頭半棘筋 の内縁、項勒帯を貫通後、後頭骨と環椎の間を通 り、延髄脊髄移行部に位置した。一方、天柱の同 側攅竹方向への刺入針は僧帽筋外縁、頭板状筋上 内縁、頭半棘筋の中央、大後頭直筋の外下縁部を 貫通後、椎骨動脈の上縁に位置した。図37右は 左天柱の体表一椎骨動脈間距離を表している。こ のご遺体の体表一椎骨動脈間距離は $40 \mathrm{~mm}$ であっ た。

(2) 肩井 ${ }^{25)}$

図38は26歳女性の肩井穴を通るMRIにて撮ら れた冠状断面像である。肩井での体表から胸膜ま での距離は、正中線に平行な力向（図 38-5）で7 $3 \mathrm{~mm}$ 、体表に垂直な方向（図38-6）で55mmであっ た。図 39 は32歳女性の肩井刺銊とX線像を示し ている。セイリン製ディスポ鍼 $50 \mathrm{~mm} 24$ 号を体表 に垂直に $25 \mathrm{~mm}$ 刺入し、骨にあたった状態でX線 撮影した。針先は第2肋骨（図39-7）にあたって おり、体表一第2肋骨間距離は約 $25 \mathrm{~mm}$ であった。 

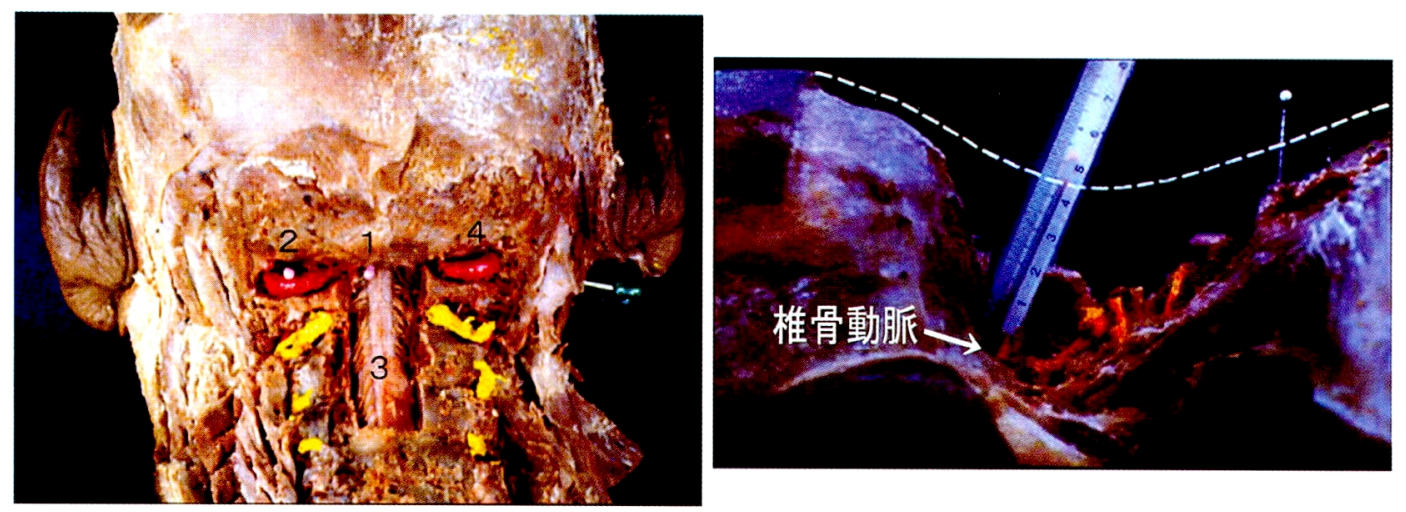

図 37 瘂門・天柱と脊髄・椎骨動脈

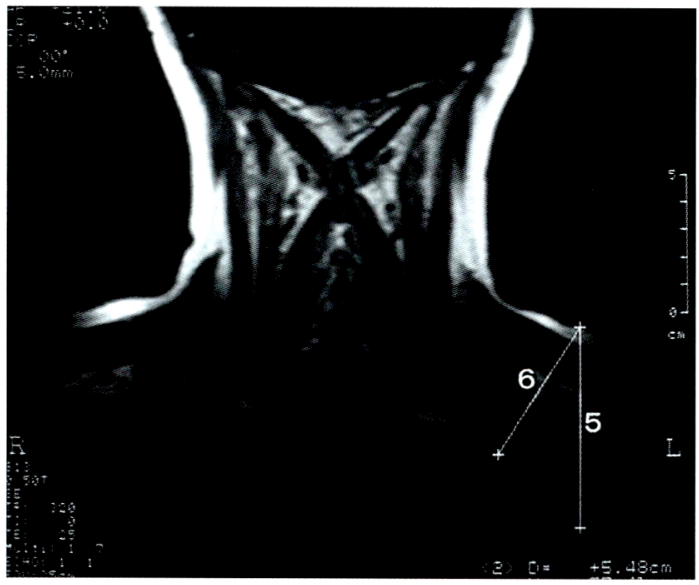

図38 肩井のMR| 像（冠状断面）

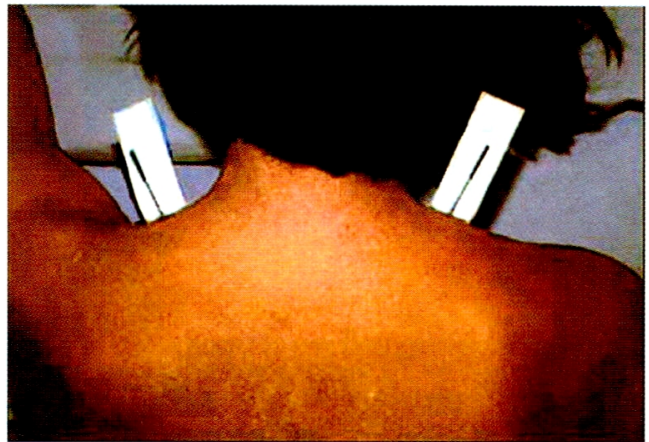

図3932歳女性の肩井刺鍼とX線像

(3) 亮肓 ${ }^{26)}$

図 40 左は左肩甲間部の解剖所見で、膀胱経二 行線と腋窩線の間の皮虞、筋、さらに第 $5 \cdot$ 第 6 肋骨を除去して胸膜（図40-8）や肺を剖出した。 左高肓への刺入針（図40-9） 亡胁骨の関係、胁骨

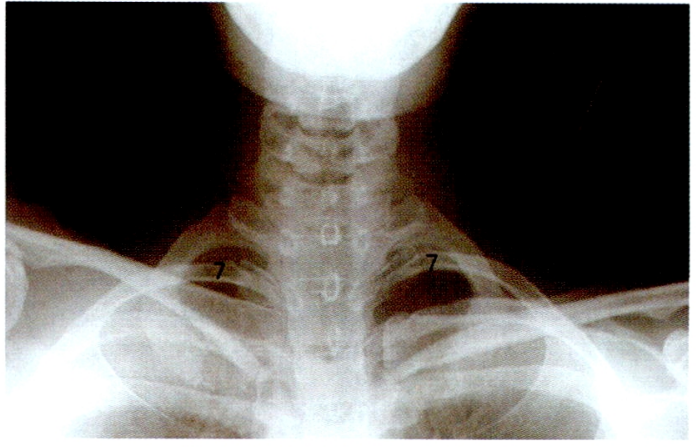

の厚さ、体表一胁骨間距離を示した。左高肓への 刺入針は第 5 肋骨上（図 40-10）に位置し、肋骨 の厚さは $10 \mathrm{~mm}$ 、体表一肋骨間距離は34mm、体表一 肋骨後面間距離は $44 \mathrm{~mm}$ であつた。図40右は標準 型の 22 歳男性の膏肓へ刺入した鍼を含む C T 横 


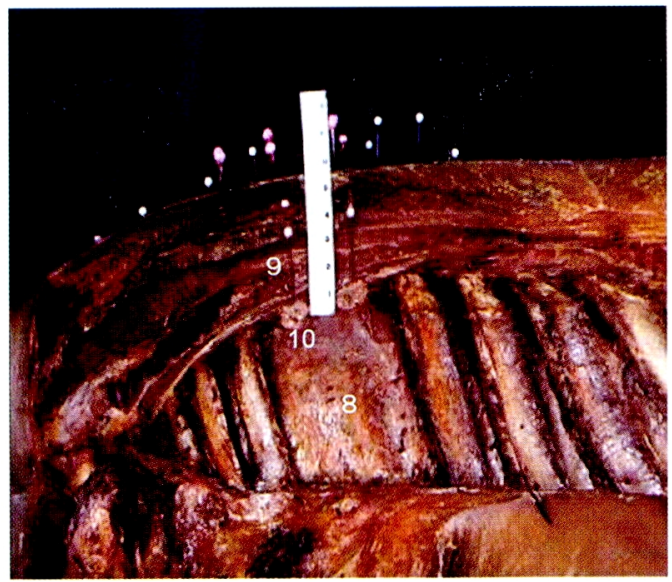

図40 亳肓刺針と遺体所見・CT横断像

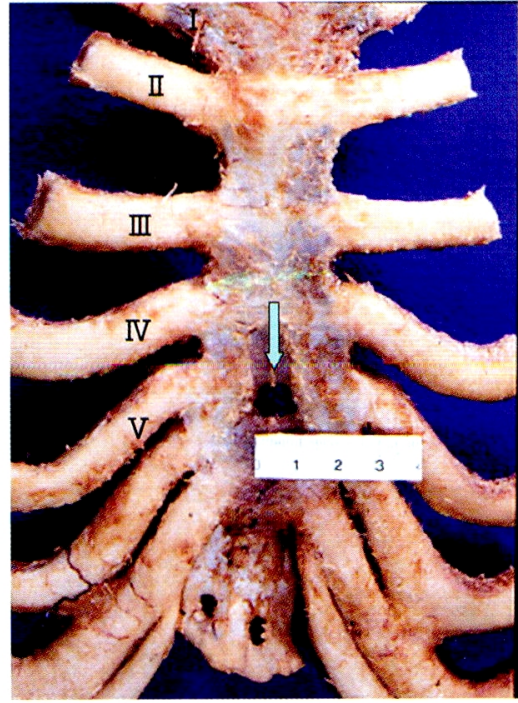

図 41 胸骨裂孔例（外面と内面）

断像である。左膏肓への刺入銊（図 40-11）は肋 骨に達し、右膏肓穴への刺入鍼（図 40-12）は肋 間に位置した。左膏肓の体表一胁骨間距離は22.7 $\mathrm{mm}$ 、胁骨の厚さは $10.9 \mathrm{~mm}$ で、体表一胁骨間距離は $33.6 \mathrm{~mm}$ であった。右膏肓の体表一胸膜間距離は28. 4mmであった。これに対し、瘦せ型40歳男性の刺 入鍼は左右ともに胁骨に到達し、体表一胸膜間距 離は左側で $29.4 \mathrm{~mm}$ 、右側で $31.8 \mathrm{~mm}$ であった（写真 省略)。

(4) 膻中 ${ }^{27)}$

図 41 は胸骨裂孔の存在した例である。裂孔は 第4肋間の高さでほぼ両乳頭間に位置した。裂孔 の形状はほぼ円形で、直径は胸骨外面で $9 \mathrm{~mm} 、 内$
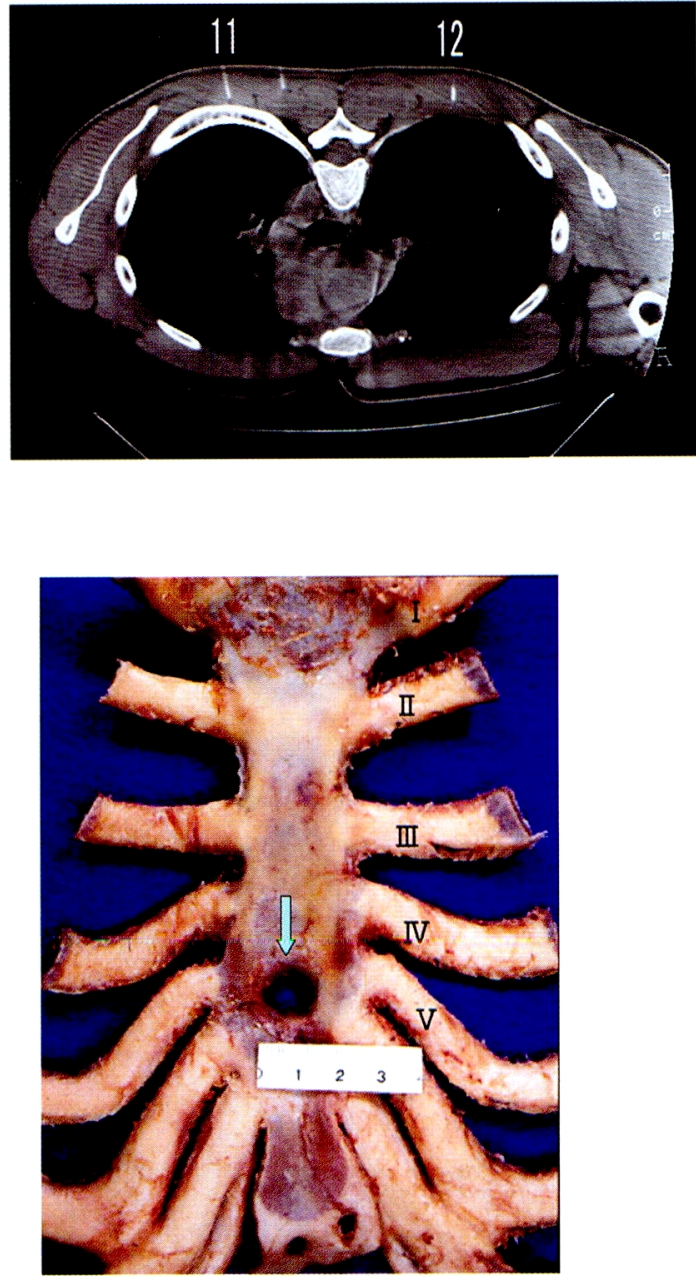

面で $13 \mathrm{~mm}$ であつた。ご遺体 159 体中 5 例（3\%） に胸骨裂孔が認められた。2 遺体で胸骨の厚さ を計測したところ胸骨の厚さの平均は $11.5 \pm 2 \mathrm{~mm}$, 最小は9mm，最大は $15 \mathrm{~mm}$ であった。31生体での体 表一胸骨後面間の平均は、やせ型男性 $17 \pm 4 \mathrm{~mm}$ 、 女性 $15.8 \pm 5 \mathrm{~mm}$ であり、体表一胸骨後面間距離の 最小值は、やせ型女性で $11 \mathrm{~mm}$ であつた。

\section{4. 考察}

（1）日本と中国での安全深度との比較

安全深度の研究は本邦での遺体を用いた松岡 ${ }^{28)}$ ・ 沢井 ${ }^{29)}$ らの報告、生体での超音波検査法やC T 画 像を用いた小林 ${ }^{30)}$ ・米山 ${ }^{31)} ら の$ 報告が散見される。 
海外でも台湾の許ら ${ }^{32}$ の生体 120 例を対象にした CT 画像での研究や中国の厳 ${ }^{19,33)}$ の遺体解剖所見 での報告のみである。

1）癋門の体表一硬膜間距離の比較

表 7 は遺体 51 体を対象とした厳 ${ }^{19,33)}$ と生体 50 例 のMRI 画像を対象とした筆者の痘門の体表一硬 膜間距離の比較したものである。厳は痘門の体表一 硬膜間距離は男性 $53.1 \pm 9 \mathrm{~mm}$ 、女性 $46.7 \pm 7 \mathrm{~mm}$ と報 告した。一方、筆者の計測では癌門の印堂方向で の体表一硬膜間距離の平均と最小値は、男性 47 $\pm 5 \mathrm{~mm} 、 37 \mathrm{~mm}$ 、女性 $41 \pm 6 \mathrm{~mm} 、 31 \mathrm{~mm}$ であった。ま た、天柱の攅竹方向での体表一椎骨間距離の平均 と最小值は男性 $49 \pm 6 \mathrm{~mm} 、 39 \mathrm{~mm}$ 、女性は $47 \pm 7 \mathrm{~mm}$ 、 36mmであった。

2）肩井の安全刺鍼距離の比較

表 8 は遺体 51 体を対象とした厳 ${ }^{19}{ }^{33)}$ と生体 44 名 を対象とした筆者の肩井の安全刺鍼距離を比較し たものである。厳は遺体での肩井穴の危険刺入深

\section{表7. 痘門の体表一硬膜間距離の比較}

\begin{tabular}{|c|c|c|c|c|c|}
\hline & & & & & (単位 : mm) \\
\hline & 㿂門 & 厳 (遺体) & 癌門 & 尾崎 & （生体 MRI像） \\
\hline 性別 & 例数 & 体表－硬膜間 & 性別 & 例数 & 体表－硬膜間 \\
\hline 男 & 21 & $53.1 \pm 9$ & 男 & 26 & $47 \pm 5$ \\
\hline 女 & 30 & $47.6 \pm 7$ & 女 & 24 & $41 \pm 6$ \\
\hline
\end{tabular}

表 8. 肩井の安全刺鍼距離の比較

\begin{tabular}{|c|c|c|c|c|c|c|}
\hline \multicolumn{3}{|c|}{ 肩井 } & 厳 (遺体) & \multicolumn{3}{|c|}{ 肩井 尾崎 (生体 CT像) } \\
\hline 性別 & 例数 & & 体表－硬膜間 & 性別 & 例数 & 体表－硬膜間 \\
\hline \multirow[t]{2}{*}{ 男 } & 21 & 左 & $56.6 \pm 12.5$ & 男 & 23 & $50 \pm 7$ \\
\hline & & 右 & $59.5 \pm 9.9$ & 女 & 21 & $47 \pm 7$ \\
\hline \multirow[t]{2}{*}{ 女 } & 30 & 左 & $55.4 \pm 10.9$ & & & (単位：mm) \\
\hline & & 右 & $55.2 \pm 11.6$ & & & \\
\hline
\end{tabular}

表 9. 䯧肓の安全深度の比較

\begin{tabular}{|c|c|c|c|c|c|c|c|}
\hline & & & & & & & (単位 $: \mathrm{mm})$ \\
\hline & 亮盲 & 店 & 交（遺体） & & & 肓 & 尾崎 (生体) \\
\hline 性別 & 例数 & & 危険刺入深度 & 性別 & BMI & 例数 & 体表－胁骨間距離 \\
\hline 男 & 21 & 左 & $36.7 \pm 11$ & 男 & 肥満 & 21 & $25.1 \pm 4.5$ \\
\hline & & 右 & $39.9 \pm 10$ & & 標準 & 45 & $20.2 \pm 3.4$ \\
\hline 女 & 30 & 左 & $35.7 \pm 12$ & & やせ & 18 & $18.8 \pm 2.3$ \\
\hline & & 右 & $34.3 \pm 7$ & 女 & 肥満 & 4 & $21.0 \pm 2.5$ \\
\hline & & & & & 標準 & 6 & $16.8 \pm 2.5$ \\
\hline & & & & & やせ & 10 & $17.4 \pm 2.3$ \\
\hline
\end{tabular}

度は、男性の左側で $56.6 \pm 12.5 \mathrm{~mm}$ 、右側では 59.5 $\pm 9.9 \mathrm{~mm}$ 、女性の左側で $55.4 \pm 10.9 \mathrm{~mm}$ 、右側で 55.2 $\pm 11.6 \mathrm{~mm}$ 之報告した。一方、筆者の報告では肩井 の体表に垂直な方向の危険刺入深度の平均值と最 小值は、男性 $50 \pm 7 \mathrm{~mm} 、 36 \mathrm{~mm}$ 、女性は $47 \pm 7 \mathrm{~mm} 、 35$ mmであった。

\section{3）高肓の安全深度の比較}

表 9 は遺体 51 体を対象とした厳 ${ }^{19,33)}$ と生体 104 名を対象とした筆者の膏肓の安全刺鍼距離を比較 したものである。厳の報告は遺体での膏肓の危険 刺入深度は、男性の左側で $36.7 \pm 11 \mathrm{~mm}$ 、右側では $39.9 \pm 10 \mathrm{~mm}$ 、女性の左側で $35.7 \pm 12 \mathrm{~mm}$ 、右側で $34.3 \pm 7 \mathrm{~mm}$ であった。一方、筆者は亮肓の体表一 肋骨間距離の平均值は男性の肥満・標準・瘦せ型 では各々 $25.1 \pm 4.5 \cdot 20.2 \pm 3.4 \cdot 18.8 \pm 2.3 \mathrm{~mm}$ 、女 性では各々 $21 \pm 2.5 \cdot 16.8 \pm 2.5 \cdot 17.4 \pm 2.3 \mathrm{~mm}$ であ ることを示した。対象が遺体と生体であるという 違いや測定部位の違いはあるものの筆者のデー夕 值に肋骨の厚さの $10 \mathrm{~mm}$ 加味すると膏肓の值と ほぼ同様な值を示す。

\section{5. 結語}

刺鍼の安全性について、遺体や生体を用いマク 口解剖学的に長年研究してきた。膻中への刺鍼で は、胸骨裂孔の出現頻度は低いが、仮に胸骨裂孔 が存在しても、極端な瘦せ型を除き、体型に関係 なく $10 \mathrm{~mm}$ 以内であれば安全と考えられる。

鍼の安全深度について中国と日本の比較を行つ た結果、対象が遺体・生体と異なることや方法の 違いから、単純に比較はできないが中国人と日本 人の刺鍼の安全深度は類似した数值を示した。癋 門は厳・尾崎共に $30 \mathrm{~mm}$ 、肩井について厳は $30 \mathrm{~mm}$ 、 尾崎はやせ型女性で $20 \mathrm{~mm} 、 そ の$ 他 の体型で $25 \mathrm{~mm}$ であった。高肓につ いて尾崎は極端なやせ型を除き19 $\mathrm{mm}$ までとした。刺鍼の安全深度に ついて、今後は遺体や生体での性 別・体型別のデータをより多く集 め、さらに精度を高めることが必 要と考えられる。 
謝 辞

ご遺体を提供して下さった篤志の方とそのご遺 族、ならびに大阪大学白菊会・徳島大学白菊会に 心より感謝いたします。

\section{V. 少数穴使用による鍼炎の臨床効果 一和文献による検討一}

坂口俊二

\section{1.はじめに}

実践的な鍼尒臨床試験の実施に向けて、その材 料（疾患や症状）選びは重要である。日本の鍼尒 臨床では腰痛、肩こり、膝関節疾患、下肢痛、頝 腕症候群などの筋骨格系の問題が多く扱われるこ とから、ランダム化比較試験（RCT）もこれらを 対象に実施されることが多い ${ }^{34-36)}$ 。しかし今後、 鍼尒の適応症をより拡大していくためには、デー タソースから、対照群との比較のない研究（症例 報告、症例集積)、対照群との比較はあるがラン ダム化されていない研究（前向き研究、後ろ向き 研究）などから材料を選出し、RCT の実施に繋 げていくことが重要であると考える。

よって本研究では医学中央雑誌からヒトを対象 にした基礎・臨床研究、なかでも少数穴使用のも のを抽出、内容の吟味・検討を行い、 RCTの材 料選出に寄与することを目的とする。

\section{2. 方法}

データソースは日本語の医学文献データベース 「医学中央雑誌」とし、検索年次は 1983 年から
2004 年の 20 年間、検索条件はヒト、原著、鍼刺 激（刺鍼法）とした。検索によってヒットした論 文のなかから、健常者を対象とした基礎研究およ び疾患や症状に対する臨床研究を抽出、内容を吟 味・検討した文献について、疾患別分類、1穴お よび2〜4穴使用の論文抽出などを行った。

\section{3. 結果}

「医学中央雑誌」によるヒット数は504文献で、 そのうち上記条件を満たしたのは 62 文献であっ た。表 10 に抽出論文の疾患別分類を示す。日常 の鍼众臨床で扱われることの多い運動器疾患（整 形外科疾患）や広い意味での疼痛疾患（神経疾患 の一部）以外にも婦人科疾患や耳鼻咽喉科・眼科 疾患など多岐にわたって研究がなされていること がわかつた。次に 1 穴使用の論文のみ概要を表 11 にまとめた。 8 論文のうち 2 論文は婦人科疾患、 なかでも安全分婏についての症例対照研究は、症 例数 137 例で最も多かった。また、基礎研究とし て血糖に及ぼす膵俞への刺鍼影響37)、高山病予防 を目的とした足三里（ST36）への施尒効果 ${ }^{38)}$ な ぞ非常に興味深い内容が含まれていた。2-4穴使 用の論文を表 12 によめた。配穴として最も臨 床的な組み合わせてとなるもので、ここでも婦人 科疾患関連論文が 12 論文中 4 論文、末梢循環障 害を主体とするもの 3 論文、また難病に指定され ているシェーグレン症候群に対する論文 ${ }^{39)}$ も抽出 された。

\section{4. 考察および結語}

表 $11 \cdot 12$ からくつかの論文を紹介し、RCT

表 10. 抽出論文の疾患別分類

整形外科疾患 : 肩関節周囲炎、脊柱管狭窄症による間欠跛行、癌の骨移転による慢性腰痛、筋疲労、 閉塞性動脈硬化症

神 経 疾 患: 攣縮性斜頝、片麻痺、片頭痛、慢性疼痛、緊張型頭痛、帯状疱疹後神経痛、病的吃逆、 末梢性顔面神経麻痺、病的共同運動

自己免疫疾患 : シェーグレン症候群、膠原病によるレイノー現象・末梢循環障害

消化器疾患: 便秘症、癒着性イレウス患者の腸蠕動

産婦人科疾患：骨盤位、安全分婏、切迫早産、分婏後および術後の腸蠕動、陣痛誘発、和痛分婏 泌 尿 器疾 患: 慢性前立腺炎、前立腺肥大症（I 期）、夜尿症、排尿障害

耳鼻咽喉科・眼科疾患 : 老人性難聴、花粉症、学童期の近視、先天眼振、大後頭神経痛による眼精疲労

そ の 他 : 冷え症、高血圧、慢性疲労症候群、舌痛、心臓神経症、アトピー性皮膚炎、

下顎枝矢状分割術後の下唇麻痺 
表 11. 1 穴使用の論文概要

\begin{tabular}{|c|c|c|c|}
\hline 疾患・症状など & 使用経穴 & 刺激法 & 症例数 \\
\hline 骨盤位 & 至 陰（BL 67） & 温众1回／日、10分間 & 68 例 \\
\hline 安全分娩 & 三陰交（SP6） & 自宅施众（間接众）1-3 壮 & 137 例 \\
\hline 前立腺肥大 & 中 極 (CV3) & 鍼 50-60 mm 刺入、施撚術 10 分 & 24 例 \\
\hline 眼精疲労 & 風 池（GB 20） & 鍼刺入、置鍼 15 分 & 17例 \\
\hline 近視 & 合 谷 (LI4) & 鍼通電、 $1 \mathrm{~Hz} .10$ 分 & 33 例 \\
\hline 血糖 & 膵 俞 (Cuishu) & 鍼刺入、得気後置鍼 10 分 & 11 例 \\
\hline 高山病 & 足三里（ST 36） & 起床後、左右に米粒大 10 壮 & 6例 \\
\hline 便通 & 内 庭（ST 44） & 求心性に斜刺 $7 \mathrm{~mm}$ 、置銊 5 分 & 51 例 \\
\hline
\end{tabular}

表 12. 2-4穴使用の論文概要

\begin{tabular}{|c|c|c|c|}
\hline 疾患・症状など & 使用経穴 & 刺激法 & 症例数 \\
\hline 冷え症 & 温溜 $($ LI 7) · 三陰交 & 置鍼 & 7例 \\
\hline レイノー現象 & 八邪 (Baxie) ・手三里（LI 10） & 鍼通電、 $1 \mathrm{~Hz} .15$ 分 & 20 例 \\
\hline 末梢循環障害 & 手三里・足三里 & $2 \mathrm{~cm}$ 刺入、置鍼 5 分 & 25 例 \\
\hline シェーグレン症候群 & 下関（ST 7）・毉風（TE 17） & 鍼通電、 $1 \mathrm{~Hz} \cdot 30 \mathrm{~Hz}$ 各 10 分 & 25 例 \\
\hline 単胎骨盤位 & 三陰交・至陰 & 众頭鍼 2 壮、米粒大 7 壮 & 17 例 \\
\hline 先天眼振 & 完骨（GB 12）・天鼎（LI 17） & 直刺 $2 \mathrm{~cm}$ 刺入、置鍼 20 分+雀啄 & 13 例 \\
\hline 眼球眼盪 & 完骨・天鼎 & 直刺 $2 \mathrm{~cm}$ 刺入、置鍼 20 分＋雀豚 & 40 例 \\
\hline 眼精疲労 & 太陽（Taiyang）・攅竹（BL 2） & $1 \mathrm{~cm}$ 刺入、鍼通電 $(5 \mathrm{~Hz} .15$ 分 $)$ & 7 例 \\
\hline 和痛分婏 & 三陰交・足三里・太衝（LR3） & 鍼通電、 $1 \mathrm{~Hz} .30$ 分以上 & 61 \\
\hline 切迫早産 & 至陰・湧泉（KI1）・是陰交 & 温众、マイクロ波 & 16 位 \\
\hline 骨盤位 & 至陰・湧泉·三陰交 & 温尒、左右各 10 壮 & 28 侈 \\
\hline 腸管の蠕動運動 & 関元 (CV 4) - 天枢 (ST 25) - 合谷 - 足三里 & 銊響後 10 分間置鍼 & 3 例 \\
\hline
\end{tabular}

に向けての改善点などについて考察する。表 11 の安全分娩を目的とした三陰交施尒の効果は、辻 内ら ${ }^{40)}$ の『母性衛生』に掲載された論文である。 その要旨は、助産院で正常分娩した 137 例を妊娠 中に施尒をしなかつた群（「非施尒群」）89例 （初産婦 57 例、経産婦 32 例）亡妊娠中に三陰交 （SP36）の自宅施令を行った群（「施令群」）48例 （初産婦 26 例、経産婦 22 例）に分類し、分娩所 要時間、出血量、会陰破裂症例数をエンドポイン トとし、2 群間で比較検討したものである。結果 としては平均分娩時間が施众群で短縮傾向、経産 婦の会陰破裂症例数は施众群で有意に少なく、施 众による重篤な副作用はみられないというものだつ た。この研究のエビデンスをより強固なものとす るには、研究開始前のプロトコールの中で各群を 初産婦、経産婦例を調整した上で割付（ランダム 化）を行うことが必要であると考える。

表 12 の眼球眼振の治療は小沢 ${ }^{41)}$ の『神経眼科』 に揭載された論文である。その要旨は40例の眼 振患者（5歳～50歳）に鍼治療を月 1 回の頻度で 3 回以上継続実施を基本として行ったもので、エ
ンドポイントは眼電図（EOG）の解析による眼 振抑制率とした。その結果、効果は著効 10 例、 有効 16 例、無効 14 例の 3 群に分かれ、特に著効 例では治療により眼振の平均 intensityは63\%まで 減少し、明らかに眼振は改善した。さらに、この 著効例は何れも 20 歳以上であり、眼振は大打性・ 高頻度そして律動性（jerky夕イプ）であったと いうものであつた。この研究は、眼振の鍼治療効 果を検討した症例集積であるが、治療として好結 果が得られ、それらの夕イプが明らかになった点 が非常に有用であると考える。次の段階としては 対象者を 20 歳以上の成人で大打性・高周波数の jerkyタイプとし、それらをランダム割付により 「銊治療群」と「従来の眼科的治療群」に分け、 その効果を検討できれば眼振を減弱させるための 治療法として鍼治療が用いることのできる方法と なり得るかが検討できると考える。

以上より、日本の鍼众臨床研究の多くは症例報 告や症例集積であるが、これらの結果を詳細に検 討することが EBM的研究の実践の近道となり得 ることが示唆された。 


\section{VI. 合谷一穴への各種鍼刺激が皮膚通電電流量に} 及ぼす影響

\section{森川和宥}

\section{1.はじめに}

鍼众臨床研究において少数の経穴で治療効果を 挙げる試みは少なく、文献的には経穴研究委員会 の坂口が報告しているが、一穴のみの報告はやは り少ないようである。

今回は「四総穴」の一つとして鍼尒臨床で頻用 され、また、鍼多刺激により全身反応を惹起させ る「合谷穴(LI4)」一穴を用いて“置鍼刺激”

(以下、置鍼)、“直流電気銊刺激” (以下、直流)、 “低周波鍼通電刺激”（以下、低周波）が、皮膚 通電電流量に及ぼす影響を“無刺激”（以下、対 照）と比較検討した。

\section{2. 方法}

対象は健康成人女性 4 名 (22歳、28歳、34歳、 35 歳）とした。刺激部位は左右合谷穴とした。 ディスポーザブルステンレス銊 $50 \mathrm{~mm} \cdot 20$ 号を用 いて、直刺で $1.2 \mathrm{~cm}$ 刺入し、置鍼では 10 分、直 流では雀豚 30 回、低周波では $1 \mathrm{~Hz} \cdot 10$ 分間で、 対照は仰臥安静のみとした。対象者には、クロス オーバー法で1週閒の間隔をあけて、対照を含む 計 4 種類の刺激を行つた。

皮膚通電電流量 ${ }^{42}$ は)イロメーターLCM（） イ医科工業（株））を用いて、手足6か所左右
計 24 か所の代表測定点で行つた（図42）。なお、 測定条件は陽極不関導子と陰極探索導子の両極短 絡時 $12 \mathrm{~V} \cdot 200 \mu \mathrm{A}$ とした。測定は仰臥安静 10 分 後 (安静時) 、刺激終了後 10 分・ 20 分· 30 分の 計 4 時点とした。測定は全て一般空調下の実習室 で行い、室温は 26.5 から $27^{\circ} \mathrm{C}$ の間であった。

皮膚通電電流量は2 4 か所の平均值で表した。 各刺激とも時系列変化は反復測定分散分析を用い、 有意差がみられた時の多重比較にはDunnet法を 用いた。

\section{3. 結果}

各種刺激による皮膚通電電流量の経時的変化で は、置鍼のみ安静時に比して刺激 10 分後で減少 傾向 $(\mathrm{p}<0.07) 、 30$ 分後で有意に減少した $(\mathrm{p}<0.05)$ 。他の刺激法では時間経過とともに皮 膚通電電流量が減少するパターンを示したが、有 意差はみられなかつた（表 13）。

\section{表13. 各種刺激による皮膚通電電流量の経時的变化}

\begin{tabular}{|c|c|c|c|c|}
\hline & 安静時 & 10 分後 & 20 分後 & 30 分後 \\
\hline 置 鍼 & $33.2 \pm 5.8$ & $23.4 \pm 6.5^{\prime}$ & $27.6 \pm 7.2$ & $22.6 \pm 7.6^{*}$ \\
\hline 直 流 & $38.7 \pm 14.4$ & $34.8 \pm 15.4$ & $31.5 \pm 16.9$ & $28.0 \pm 16.8$ \\
\hline 低周波 & $33.4 \pm 15.2$ & $22.6 \pm 12.2$ & $18.1 \pm 11.3$ & $19.6 \pm 9.8$ \\
\hline 無刺激 & $43.2 \pm 14.0$ & $41.0 \pm 6.5$ & $37.4 \pm 5.5$ & $36.0 \pm 7.0$ \\
\hline
\end{tabular}

\section{4.考察および結語}

今回、無刺激の皮膚通電電流量は安静時から時 間経過ともに減少する傾向を示したが、有意差は
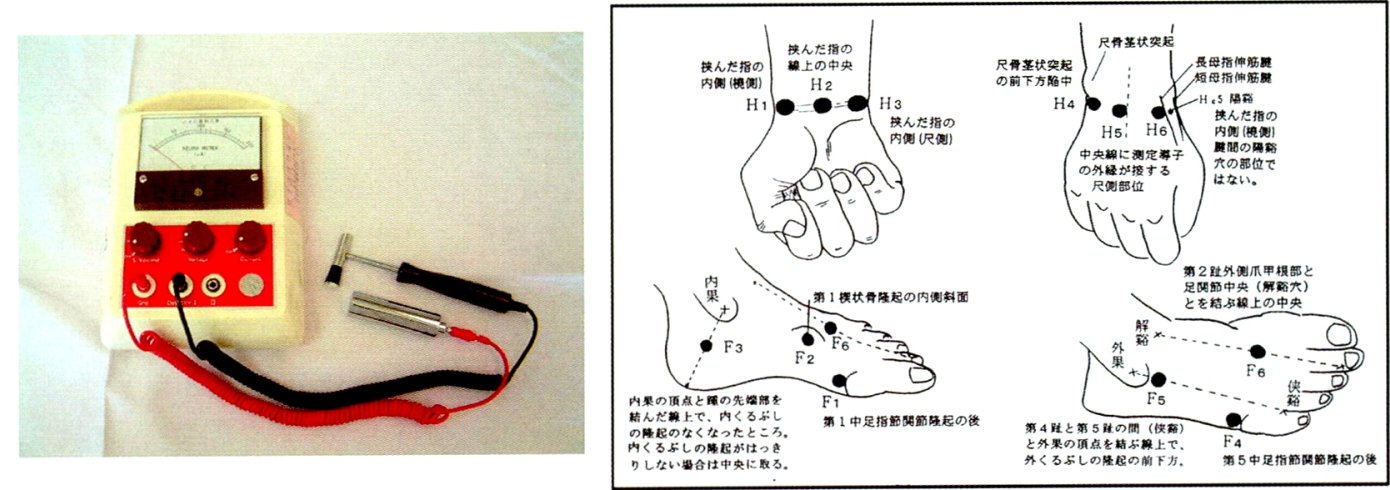

図42 ノイロメータ (Neur ometerLCM) と代表測定点部位 
みられなかった。これは仰臥安静保持による皮膚 交感神経機能の低下を反映しているものと考える。 直流電気鍼刺激も同様の傾向を示し、変化量も無 刺激と比べ大きかったが、有意差はみられなかっ た。低周波鍼通電では、20分後から 30 分後で皮 膚通電電流量がやや高くなっており、20分後ま での安静時との変化量は他の刺激法と比べ最も大 きかったが、有意差はみられなかつた。置鍼刺激 では、刺激 10 分後に皮膚通電電流量が減少傾向 を示し、 20 分後には少し増加したが、 30 分後に は有意に減少した。

皮膚通電抵抗 ${ }^{42)}$ は交感神経機能と密接な関係が あり、皮膚における皮膚通電抵抗の主体は表皮角 質層とその水分含有量に起因するといわれ、その 変化は皮膚交感神経の支配下にある汗腺と毛囊が 影響すると考えられている。すなわち、皮膚の交 感神経が興奮すると、真皮、表皮の細胞透過性が 高まり、電解質液が移動しゃすくなるため、限局 した角質において水分含有量が増加し、皮膚の電 気抵抗が低下して、電気が流れやすくなると考え られる。

よって、今回の結果から刺激による反応パター ンは異なっており、なかでも置鍼刺激が経時的に 皮膚交感神経機能を低下させたことが示唆される。 置鍼刺激は直流電気鍼刺激や低周波鍼通電刺激の ように他動的にからだを摇さぶるのではなく、刺 激による反応をその対象者に委ねる方法であり、 これが皮膚交感神経機能を低下させるのに優位に 働いたものと考える。

坂口 ${ }^{43}$ は鍼尒治療による自律神経反応を血圧・ 脈拍数、皮膚通電電流量と加速度脈波で検討した ところ、降圧剤など循環系に影響を与える薬剤を 服用していない患者では、脈拍数と皮膚通電電流 量の有意な減少と加速度脈波の波高比（d/a）の 有意な減少と指尖容積脈波増大係数 (PTGAI) の 有意な増加がみられたと報告している。この結果 は鍼炎治療により、脈拍数と皮膚通電電流量の減 少にみる副交感神経機能の亢進（交感神経機能の 低下）とともに加速度脈波の結果にみる交感神経 機能の亢進による機能的な動脈壁の緊張状態を作 り出すことを示唆している。

今回の反応が合谷穴の特異的反応であるとする
のは早計であるが、臨床的には各種の痛みのコン トロールに合谷穴を頻用し、その時の局所の反応 は強い緊張と圧痛を伴うことが多い。そこに鍼を 刺入し置鍼をすることで京進している交感神経機 能を低下させた結果が痛みの軽減の要因になって いると考える。鍼众治療は場所（経穴）と刺激方 法が刺激後の反応を決定する重要な要素となるこ とが改めて示唆された。

\section{文 献}

1）石原 明. 経絡私考 -針众の本道己経絡治療-. 医道の日. 1959; 10: 3-6.

2）米山博久. 経絡否定論. 医道の日. 1952；2: 28.

3）山田鑑照，尾崎朋文，坂口俊二，森川和宥. 経絡論争期の経絡・経穴についての基礎研究. 全日鍼尒会誌. 2002；52(5)：529-47.

4）山田鑑照. 経穴の解剖学的考察. 東洋療学協 会誌. 1986; 10: 53-56.

5）山田鑑照. 経穴の解剖学的考察（その2). 東 洋療学協会誌. 1987; 10: 77-9.

6) 畑本平男. 経絡 - 経穴の神経解剖学的研. 東 方医学. $2000 ; 16(2): 21-9$.

7）豊田勝良. 上肢およびその周辺に位置する経 絡・経穴と人体構成要素との関連についての 肉眼解剖学的研究. 名市大医誌. 1989; 40(2): 449-71.

8）堀田康明, 馬淵良生, 豊田勝良, 渡 仲三. 経 穴 (つぼ) の組織学的構造に関する研究 -皮 膚の組織学的構造と経穴 (つぼ) -. 全日鍼尒 会誌. 1984; 34(2): 81-4.

9）倉林 譲. 針麻酔の臨床と基礎 -経穴の組織 所見-. 克誠堂出版. 1979: 143-53.

10）渡 仲三, 黒野保三, 石野龍代, 平松由江, 堀 茂，中村弘則ら. 経穴の実在の有無証明の ための実験的、形態学的研究. 全日鍼尒会誌. 1982; 31(4): 310-14.

11）長浜善夫.針食の医学. 創元医学新書. 1982: 159-61.

12）北出利勝, 山本茂由, 田中淳子, 森川和宥, 兵頭正義. 明瞭な経絡現象を呈する一症例に ついて (第一報). 全日鍼尒会誌. 1983；33(1): 
33-41.

13）北出利勝，兵頭正義. 中国の経絡現象 - 循環 感伝現象（PSC）の研究特集を読んで. 針食. 1983; 4(2): 71-4.

14）山田鑑照, 星野洸, 渡仲三. 循経感伝現象が リンパ管において発現する機序について. 医 道の日. 1995; 54(3): 22-7.

15）間中善雄. 経絡を中心とした中国医学 -経絡 敏感人に関する観察- 医学のあゆみ. 1982; 120(9): C-410.

16）何智明, 杉充扸訳. 経絡感伝現象研究の進展 (新中医、1981 年 12 号)。中医臨床 1982; 3(2): 77-81.

17）芹沢勝助. 現代日本の鍼众 -針众の現状と将 来への展望-. 医道の日. 1975: 28-43.

18）厳振国. 経穴断面解剖図解 (頭頸、胸部). 上海科学技術出版社. 1990 .

19）厳振国. 頭頸部「危険経穴」刺針安全深度的 研究. 上海鍼众雑誌. 1996; 15(3): 37.

20）厳振国, 張建華, 顧洪川, 余安勝, 趙英侠, 毛 根金ほか, 王財源邦訳. 頭頸部の危険経穴に おける刺針安全深度の研究（第一報）。全日 鍼尒会誌. 1997; 47(3): 191-5.

21）張建華, 㛜振国, 顧洪川, 毛根金, 余安勝, 趙 英侠ほか. 胸部の経穴における刺針安全深度 の研究. 東洋医とペインクリニック.1998; 28(4): 139-42.

22）張建華, 厳振国, 顧洪川, 毛根金, 魏鴻熙, 趙 英侠ほか. 背腰部の経穴における刺針安全深 度の研究. 東洋医とペインクリニック. 1998; 28(4): 143-6.

23）張海東, 杜振蘭, 厳振国, 余安勝, 李鳳梅. 隅 岡俊浩邦訳. 風池、風府、瘂門穴の解剖構造 に関するマルチメディア研究. 東洋医とペイ ンクリニック. 2004; 27(1,2): 8-16.

24）尾崎朋文, 野々井康治. 遺体解剖および生体 でのMRI 画像よりみた痘門・天柱穴への刺 鍼の安全な方向と深度について。医道の日. 1995; 54(6): 12-23.

25）尾崎朋文. 遺体解剖および生体での MRI・X 線画像よりみた肩井穴への刺鍼の安全な方向 と深度について。医道の日. 1994; 53(10): 25-
36.

26）尾崎朋文，吉田篤. 膏肓穴刺銊の安全深度の 検討. 全日鍼众会誌. 2002; 52(4)：413-20。

27）尾崎朋文, 米山榮. 膻中穴刺鍼の安全深度の 検討 (1). 全日鍼众会誌. 2000；50(1)：103-10.

28）松岡憲二, 北村清一郎：膏肓穴の局所解剖所 見. 全日鍼众会誌. 1989；39(1)：154.

29）沢井勝三, 椎野瑞穂, 木村明彦, 五味敏昭. 鍼众医学の立場から見た人体横断解剖 (1). 全日鍼尒会誌. 1991；41(3)：271-80.

30）小林英俊, 宮本俊和. 気胸の防止について. 全日銊众会誌. 1986；36(3)：235.

31）米山榮. 鍼尒臨床の向上をめざして (1) - 合 併症の回避-. 医道の日. 1992; 573: 30-4.

32）許清寅, 林昭庚. 以電脳断層掃描撮影術探討 胸部各経穴安全深度. 中華雑誌. 1992；50: 388-9.

33）王財源，吉備登訳，張建華，厳振国. 背腰部 の経穴における刺針安全深度の研究. 東洋医 とペインクリニック. 1998; 28(4): 143-6.

34）宮本俊和, 濱田 淳, 和田恒彦, 寺田和史, 市 川あゆみ，鍋倉賢治、マラソン後の筋痛と筋 硬度に対する円皮鍼の効果. 日東医誌. 2003; 54(5): 939-44.

35) Tsukayama $\mathrm{H}$, Yamashita $\mathrm{H}$, Tanno $\mathrm{Y}$. Randomised Controlled Trial Comparing the Effectiveness of Electroacupuncture and TENS for Low Back Pain: A Preliminary Study for a Pragmatic Trial. Acupunct Med. 2002; 20(4): 175-80.

36）古屋英治, 名雪貴峰, 八亀真由美, 古海博子, 篠原隆三，二村隆一ら．肩こりに及ぼす円皮 鍼の効果 -偽鍼を用いた比較試験. 全日鍼众 会誌. 2002; 52(5): 553-61.

37）渡邊吉隆, 森 優也. 膵俞穴への刺激が血糖 に及ぼす影響について. 東洋療学協会誌. 2001; 25: 20-5.

38）本間淑文，村居眞琴.高山病に対する施尒刺 激の予防的効果について. 全日鍼尒会誌. 1991; 41(3): 346-52.

39）小俣 浩, 山口 智, 大野修嗣, 土肥 豊. シェー グレン症候群 (SjS) 患者の乾燥症状に対す 
る銊治療効果．日温気候物理医会誌．2000； 63(2): 79-90.

40）辻内敬子, 形井秀一. 安全な分娩を目的とし て三陰交施食の効果. 母性衛生. 2002；43(1): 148-55.
41）小沢治夫. 眼球眼振の治療 -第 1 報 鍼治療-. 神経眼科. 1989; 6: 207-17.

42）北村 智. 鍼尒特殊治療法. 第 3 版. 大阪. 春 木印刷所. 2004: 1-25.

43）坂口俊二. 未梢循環に対する銊众治療の効果. 大阪私立短期大学協会教員個別研究報告書. 2001; 40: 1-5.

THE 54 th ANNUAL MEETING (FUKUOKA)

Workshop II (Meridian Point)

\title{
An Anatomical and Clinical Examination of Meridian and Meridian Point
}

\author{
YAMADA Kansho' ${ }^{1)}$, OZAKI Tomofumi'i), MATSUOKA Kenji ${ }^{3)}$, \\ SAKAGUCHI Shunji ${ }^{4)}$, WANG Cai Yuan ${ }^{4)}$, MORIKAWA Kazuhiro", \\ MORI Shyungo $0^{2)}$, YOSHIDA Atsushi', KITAMURA Seiichiro" ${ }^{7}$, \\ YONEYAMA Sakae ${ }^{8)}$, TANIGUCHI Kazuhisa ${ }^{3)}$
}

The Research Committee for the Meridian Point, The Japan Society of Acupuncture and Moxibustion

1) Trident College of Sports and Health Science

2) Morinomiya College of Medical Arts and Science

3) Meiji School of Oriental Medicine

4) Kansai College of Oriental Medicine

5) Toyo Medical College

6) Osaka University Graduate School of Dentistry, Department of Oral Anatomy and Neurobiology

7) The University of Tokushima Graduate School, Institute of Health Biosciences, Department of Oral and Maxillofacial Anatomy

8) Yoneyama Clinic

\section{Abstract}

Six members of the Research Committee for the Meridian Point (former Committee for the Meridian Point) reported on three themes regarding meridian and acupuncture point at Workshop II of the 54 th Science Rally of The Japan Society of Acupuncture and Moxibustion held in Fukuoka.

1 st theme: Anatomical examination of the meridian and meridian point.

1) Anatomic structure showing path and meridian running. (Kenji Matsuoka): Similarity of meridian pathway and course of nerve and blood vessels in cadaver.

2) Gross anatomical study of meridian and acupuncture point in upper limbs (Kansho Yamada): Doctoral study of Katsuyosi Toyoda, former Nagoya City University School of Medicine researcher and Yamada's 
study (Relation between running of meridian \& acupuncture point and subdermal nerve \& blood vessels) were reported.

2nd theme: Study of acupuncture safety depth in Japan and China.

1) Research and progress situation of acupuncture safety depth in China. (WANG Cai Yuan): Data of Yan Zhenguo, professor of anatomy at Shanghai University of Traditional Chinese Medicine, an authority on the study of acupuncture safety depth and progress situation of recent study of acupuncture safety depth in China.

2) Retrospective study of acupuncture safety depth (Tomofumi Ozaki): Study of acupuncture safety depth published by Ozaki to date and comparative study alongside Prof. Yan Zhenguo data.

3 rd theme: Examination of clinical effect of a few meridian points.

1) Acupuncture clinical effect using a few meridian points (Syunji Sakaguchi): Paper research and analysis of acupuncture clinical effects using 1-4 meridian points of Japana Centra Revuo Medicina.

2) Inflence on skin energizing current by various acupuncture stimulation of LI4 (Gokoku)(Kazuhiro Morikawa): Influence on the amount of skin energizing current by acupuncture stimulation, direct current electricity stimulation and stimulation of electroacupuncture to LI4.

Zen Nippon Shinkyu Gakkai Zasshi (Journal of the Japan Society of Acupuncture and Moxibustion: JJSAM). 2006; 56(1): 27-56.

Key words: meridian, meridian point, nerve, blood vessel, acupuncture and moxibustion, a few meridian points, acupuncture safety depth, clinical effect 